

\section{AVAILABILITY OF BOOKS AND MAPS OF THE U.S. GEOLOGICAL SURVEY}

Instructions on ordering publications of the U.S. Geological Survey, along with the last offerings, are given in the current-year issues of the monthly catalog "New Publications of the U.S. Geological Survey." Prices of available U.S. Geological Survey publications released prior to the current year are listed in the most recent annual "Price and Availability List." Publications that are listed in various U.S. Geological Survey catalogs (see back inside cover) but not listed in the most recent annual "Price and Availability List" are no longer available.

Prices of reports released to the open files are given in the listing "U.S. Geological Survey Open-File Reports," updated monthly, which is for sale in microfiche from the U.S. Geological Survey Books and Open-File Reports Sales, Box 25425, Denver, CO 80225.

Order U.S. Geological Survey publications by mail or over the counter from the offices given below.

\section{BY MAIL}

\section{Books}

Professional Papers, Bulletins, Water-Supply Papers, Techniques of Water-Resources Investigations, Circulars, publications of general interest (such as leaflets, pamphlets, booklets), single copies of periodicals (Earthquakes \& Volcanoes, Preliminary Determination of Epicenters), and some miscellaneous reports, including some of the foregoing series that have gone out of print at the Superintendent of Documents, are obtainable by mail from

\section{U.S. Geological Survey, Books and Open-File Report Sales Box 25425 \\ Denver, CO 80225}

Subscriptions to periodicals (Earthquakes \& Volcanoes and Preliminary Determination of Epicenters) can be obtained ONLY from

\section{Superintendent of Documents \\ U.S. Government Printing Office Washington, DC 20402} Documents.)

(Check or money order must be payable to Superintendent of Maps

For maps, address mail order to

\section{U.S. Geological Survey, Map Sales Box 25286 \\ Denver, CO 80225}

Residents of Alaska may order maps from

\author{
U.S. Geological Survey, Map Sales \\ 101 Twelfth Ave., Box 12 \\ Fairbanks, AK 99701
}

\section{OVER THE COUNTER}

\section{Books}

Books of the U.S. Geological Survey are available over the counter at the following U.S. Geological Survey offices, all of which are authorized agents of the Superintendent of Documents.

- ANCHORAGE, Alaska-4230 University Dr., Rm. 101

- ANCHORAGE, Alaska-605 West 4th Ave., Rm G-84

- DENVER, Colorado-Federal Bldg., Rm. 169, 1961 Stout St.

- LAKEWOOD, Colorado-Federal Center, Bldg. 810

- MENLO PARK, California-Bldg. 3, Rm. 3128, 345 Middlefield Rd.

- RESTON, Virginia-National Center, Rm. 1C402, 12201 Sunrise Valley Dr.

- SALT LAKE CITY, Utah-Federal Bldg., Rm. 8105, 125 South State St.

- SAN FRANCISCO, California-Customhouse, Rm. 504, 555 Battery St.

- SPOKANE, Washington-U.S. Courthouse, Rm. 678, West 920 Riverside Ave.

- WASHINGTON, D.C.-U.S. Department of the Interior Bldg., Rm. 2650, 1849 C St., NW.

\section{Maps}

Maps may be purchased over the counter at the U.S. Geological Survey offices where books are sold (all addresses in above list) and at the following Geological Survey offices:

- ROLLA, Missouri-1400 Independence Rd.

- FAIRBANKS, Alaska-New Federal Building, 101 Twelfth Ave. 
Chapter W

\title{
Sedimentology and Depositional History of the Upper Triassic Chinle Formation in the Uinta, Piceance, and Eagle Basins, Northwestern Colorado and Northeastern Utah
}

\author{
By RUSSELL F. DUBIEL
}

A multidisciplinary approach to research studies of sedimentary rocks and their constituents and the evolution of sedimentary basins, both ancient and modern 


\title{
U.S. DEPARTMENT OF THE INTERIOR MANUEL LUJAN, JR., Secretary
}

\author{
U.S. GEOLOGICAL SURVEY
}

Dallas L. Peck, Director

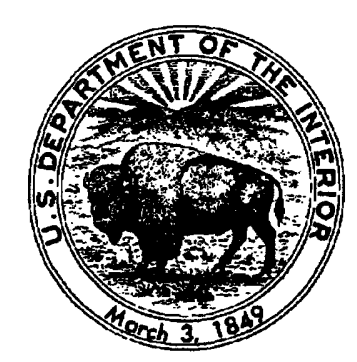

Any use of trade, product, or firm names in this publication is for descriptive purposes only and does not imply endorsement by the U.S. Government

UNITED STATES GOVERNMENT PRINTING OFFICE: 1992

For sale by the

Books and Open-File Reports Section

U.S. Geological Survey

Federal Center

Box 25425

Denver, CO 80225

\section{Library of Congress Cataloging-in-Publication Data}

Dubiel, Russell F.

Sedimentology and depositional history of the Upper Triassic Chinle Formation in the Uinta, Piceance, and Eagle basins, northwestern Colorado and northeastern Utah / by Russell F. Dubiel.

p. $\quad \mathrm{cm}$. - (Evolution of sedimentary basins-Uinta and Piceance basins ; ch. W) (U.S. Geological Survey bulletin ; 1787)

"A multidisciplinary approach to research studies of sedimentary rocks and their constituents and the evolution of sedimentary basins, both ancient and modern."

Supt. of Docs. no.: । 19.3:B1787W

1. Geology, Stratigraphic-Triassic. 2. Geology-Colorado.

3. Geology -Utah. 4. Chinle Formation. I. Title. II. Series. III. Series: U.S. Geological Survey bulletin ; 1787.

QE75.B9

no. $1787-W$

[QE679]

$557.3 \mathrm{~s}-\mathrm{dc} 20$

[551.7'09788]

$91-23188$ 


\title{
CONTENTS
}

\author{
Abstract W1 \\ Introduction W1 \\ Previous work W2 \\ Geologic setting W4 \\ Stratigraphy W4 \\ Sedimentology W6 \\ Lithofacies and depositional environments W6 \\ Valley-fill and active channel-fill deposits W6 \\ Lateral-accretion deposits W7 \\ Floodplain deposits W10 \\ Lacustrine-delta and crevasse-splay deposits W16 \\ Lacustrine deposits W17 \\ Eolian deposits W19 \\ Depositional systems and paleogeography W19 \\ Paleoclimate W22 \\ Conclusions W22 \\ References cited W22
}

\section{FIGURES}

\section{1, 2. Maps showing:}

1. Schematic reconstruction of Late Triassic paleogeography on Colorado

Plateau and adjacent regions $\mathbf{W} 2$

2. Study area in northwestern Colorado and northeastern Utah W3

3. Chart showing correlation of stratigraphic nomenclature of Upper Triassic strata W4

4. Measured stratigraphic sections of Upper Triassic Chinle Formation W8

5-14. Photographs showing:

5. Fluvial valley-fill conglomerate and sandstone of Gartra Member W13

6. Purple-mottled sandstones of Temple Mountain Member W13

7. Lower part of red siltstone member of Chinle Formation near Derby Junction W14

8. Upper part of red siltstone member of Chinle Formation near Derby Junction W14

9. Intersecting sandstone-filled mudcracks in lower part of red siltstone member of Chinle Formation near Derby Junction W15

10. Pseudoanticlines in paleosols of middle part of red siltstone member of the Chinle Formation near Derby Junction W15

11. Root alteration haloes in red siltstone member of Chinle Formation near East Brush Creek, Eagle basin W16

12. Lacustrine-deltaic strata in Moss Back Member of Chinle Formation, San Rafael Swell W17

13. Lacustrine deposits in Chinle Formation W18

14. Eolian deposits at top of Chinle Formation, East Brush Creek, Eagle basin W20

15. Map showing schematic reconstruction of Chinle depositional systems in Uinta, Piceance, and Eagle basins 


\section{TABLE}

1. Locations of measured sections of the Chinle Formation in the Uinta, Piceance, and Eagle basins, northwestern Colorado and northeastern Utah W12 


\title{
Sedimentology and Depositional History of the Upper Triassic Chinle Formation in the Uinta, Piceance, and Eagle Basins, Northwestern Colorado and Northeastern Utah
}

\author{
By Russell F. Dubiel
}

\begin{abstract}
Lithofacies analysis was used to examine depositional systems of the Upper Triassic Chinle Formation in the Uinta, Piceance, and Eagle basins in northwestern Colorado and northeastern Utah. Lithofacies analysis identified deposits of valley fills and active channel fills, point bars of moderate- to high-sinuosity fluvial systems, floodplains containing paleosols and rhizoliths, lakes and lacustrine deltas, and eolian sand sheets.

Lateral facies relations determined from field relations and stratigraphic cross sections depict the paleogeography at the time of Chinle deposition. The ancestral Uncompahgre and Front Range uplifts in Colorado supplied clastic detritus to the depositional basin. Fluvial systems flowed west and northwest from the bounding highlands and deposited sediment within paleovalleys and channels and on associated floodplains. Fluvial systems graded distally into lacustrine and lacustrinedeltaic systems in the southern and eastern Uinta and Piceance basins. In the Eagle basin, the close of Chinle time is marked by eolian sand-sheet deposition, reflecting the change from a tropical monsoonal climate earlier in the Late Triassic to drier conditions at the close of the Late Triassic.
\end{abstract}

\section{INTRODUCTION}

The Upper Triassic Chinle Formation is a sequence of continental rocks that was deposited in a back-arc cratonic basin (Dickinson, 1981). A magmatic-volcanic arc on the western and southwestern margin of the Triassic continent provided both volcanic ash and clastic detritus to the Chinle

Manuscript approved for publication, May 15, 1991. depositional basin, which encompassed a large part of the Colorado Plateau and the regions adjacent to it. The Chinle depositional basin can be subdivided in this area into a major and a minor depocenter.

The major part of the Chinle depositional basin was centered near the Four Corners area of Colorado, Utah, Arizona, and New Mexico and was north of the Mogollon Highlands and south of the ancestral Rocky Mountains (fig. 1) (Stewart and others, 1972; Blakey and Gubitosa, 1983; Dubiel, 1983, 1989a, b; Busbey-Spera, 1988). Detritus was shed northward and westward into this part of the Chinle basin from the Mogollon Highlands, which lay to the south, and southward and westward off the ancestral Rocky Mountains, which lay to the north. The ancestral Rocky Mountains consisted of the ancestral Uncompahgre Highlands and the ancestral Front Range and several minor ranges. Fluvial and lacustrine-deltaic depositional systems flowed north and west off of the Mogollon Highlands and south and west off of the ancestral Uncompahgre and Front Range highlands into the southern part of the Chinle depositional basin. A second smaller part of the Chinle depositional basin was coincident with the areas of the present-day Eagle basin in western Colorado and Uinta and Piceance basins in northwestern Colorado and northeastern Utah. The ancestral Uncompahgre Highlands and the ancestral Front Range also contributed clastic detritus northward and westward to this smaller part of the Chinle depositional basin.

Considerable effort has been focused on delineating stratigraphic and sedimentologic relations within the Chinle Formation of southeastern Utah, northern Arizona, and northern New Mexico (for example, Stewart and others, 1972; Blakey and Gubitosa, 1983; Dubiel, 1987a, b, c, 


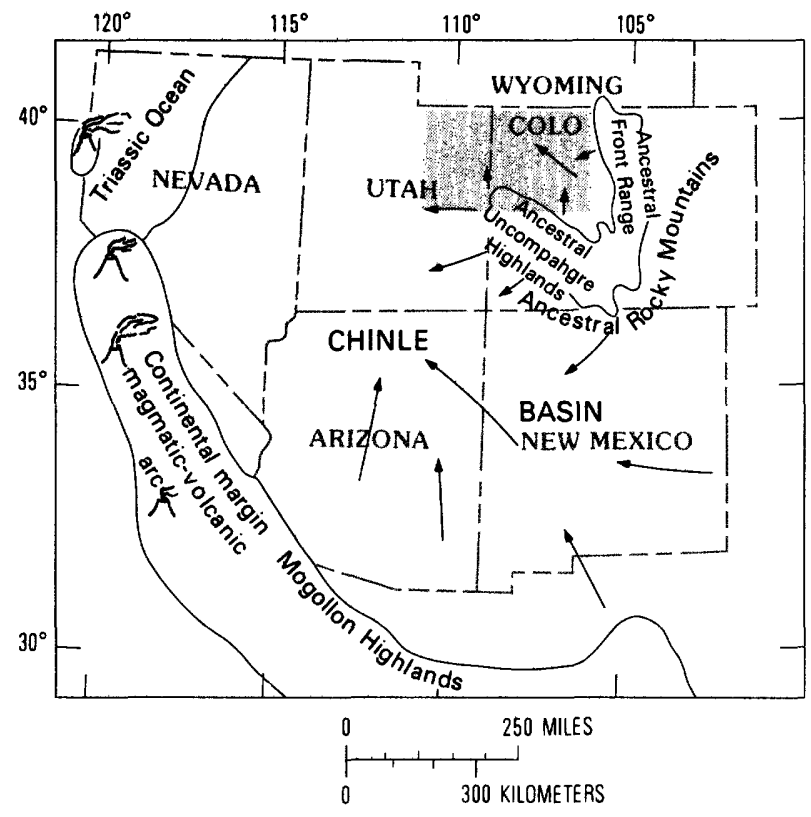

Figure 1. Schematic reconstruction of Late Triassic paleogeography on the Colorado Plateau and adjacent regions. Arrows depict general transport directions of clastic sediment. Details of study area (shaded) are in figure 2.

1989a, b; Lucas and Hayden, 1989); however, few research efforts employing modern sedimentologic techniques have been applied to the Chinle in northwestern Colorado and northeastern Utah.

This study examined the sedimentology and depositional history of the Chinle Formation in outcrops in the Uinta, Piceance, and Eagle basins of northwestern Colorado and northeastern Utah (fig. 2). Upper Triassic rocks are exposed in four widely separated areas within the broad region outlined for this study: (1) the Eagle basin and White River uplift in western Colorado, (2) the Uinta and Piceance basins in northwestern Colorado and northeastern Utah in the vicinity of Dinosaur National Monument and the Uinta Mountains, (3) the San Rafael Swell in east-central Utah, and (4) western Colorado and eastern Utah in the canyon country near Moab, Utah. This report presents the results of detailed sedimentologic examination of outcrops in the Uinta, Piceance, and Eagle basins and some preliminary data from the San Rafael Swell and near Moab.

Stratigraphy of the Chinle Formation and related Upper Triassic strata on the Colorado Plateau and correlations with Upper Triassic rocks northward into Wyoming are complicated by a combination of varied historical stratigraphic nomenclature, a lack of stratigraphic and biostratigraphic marker horizons within the continental strata, and the laterally persistent, but generally poorly exposed character of the Chinle. Exact stratigraphic relations between units are further complicated by rapid lateral facies changes typical of continental rocks. This report does not establish new stratigraphic nomenclature but rather discusses the units in terms of genetic sedimentologic units and previously published stratigraphy.

Acknowledgments.-This paper has benefited from constructive reviews by Samuel Johnson and Robert B. O'Sullivan, U.S. Geological Survey. Gary Skipp, U.S. Geological Survey, provided invaluable assistance in the field. Steven C. Good, University of Colorado at Boulder, and J. Michael Parrish, Northern Illinois University, provided identifications of invertebrate and vertebrate fossils, respectively, and both collaborated on discussions and additional aspects of cooperative interdisciplinary research. The work on which this report is based was supported by the U.S. Geological Survey Evolution of Sedimentary Basins Program.

\section{PREVIOUS WORK}

The Chinle Formation has been the focus of many reports related to Triassic stratigraphy, Late Triassic paleontology, and economic uranium-vanadium deposits. Many of those reports discuss that part of the Chinle deposited in and around the Four Corners region of Utah, Colorado, New Mexico, and Arizona. An inclusive review of previous literature on the Chinle Formation and related Triassic rocks on the Colorado Plateau is in Stewart and others (1972). More recent reports, particularly those related to sedimentologic studies, are summarized in Dubiel (1987a, c, 1989a, b), Dubiel, Good, and Parrish (1989), and Dubiel and Skipp (1989).

In contrast to the many publications on the Chinle in the Four Corners region, relatively few publications deal with the Chinle Formation of northwestern Colorado and northeastern Utah. Despite being few in number, these publications describe the complex stratigraphy of Upper Triassic rocks and provide the basis for subsequent detailed studies both in the northern part of the Colorado Plateau and farther to the north in Wyoming. The Shinarump Member and Chinle Formation were recognized by most geologists working in the region (see, for example, Thomas and others, 1945; Kinney, 1955). Thomas and Krueger (1946) first used the terms Stanaker Formation and Gartra Grit Member for the Upper Triassic rocks of the Uinta Mountains that they considered lithologically distinct from the Chinle. Keller $(1952,1953)$ suggested that the presence of analcime in the Chinle near Vernal, Utah, indicates that those rocks are correlative with the analcime-bearing Upper Triassic Popo Agie Formation in Wyoming. MacLachlan (1957) discussed Triassic stratigraphy in parts of Utah and Colorado. Poole and Stewart (1964) extended correlations of Upper Triassic strata on the Colorado Plateau northward into the Uinta Mountains. Sikich (1965) briefly discussed Upper Triassic stratigraphy in the eastern Uinta Mountains. High and Picard (1967), McCormick and Picard (1969), and High and others (1969) supported Keller's contention and extended 


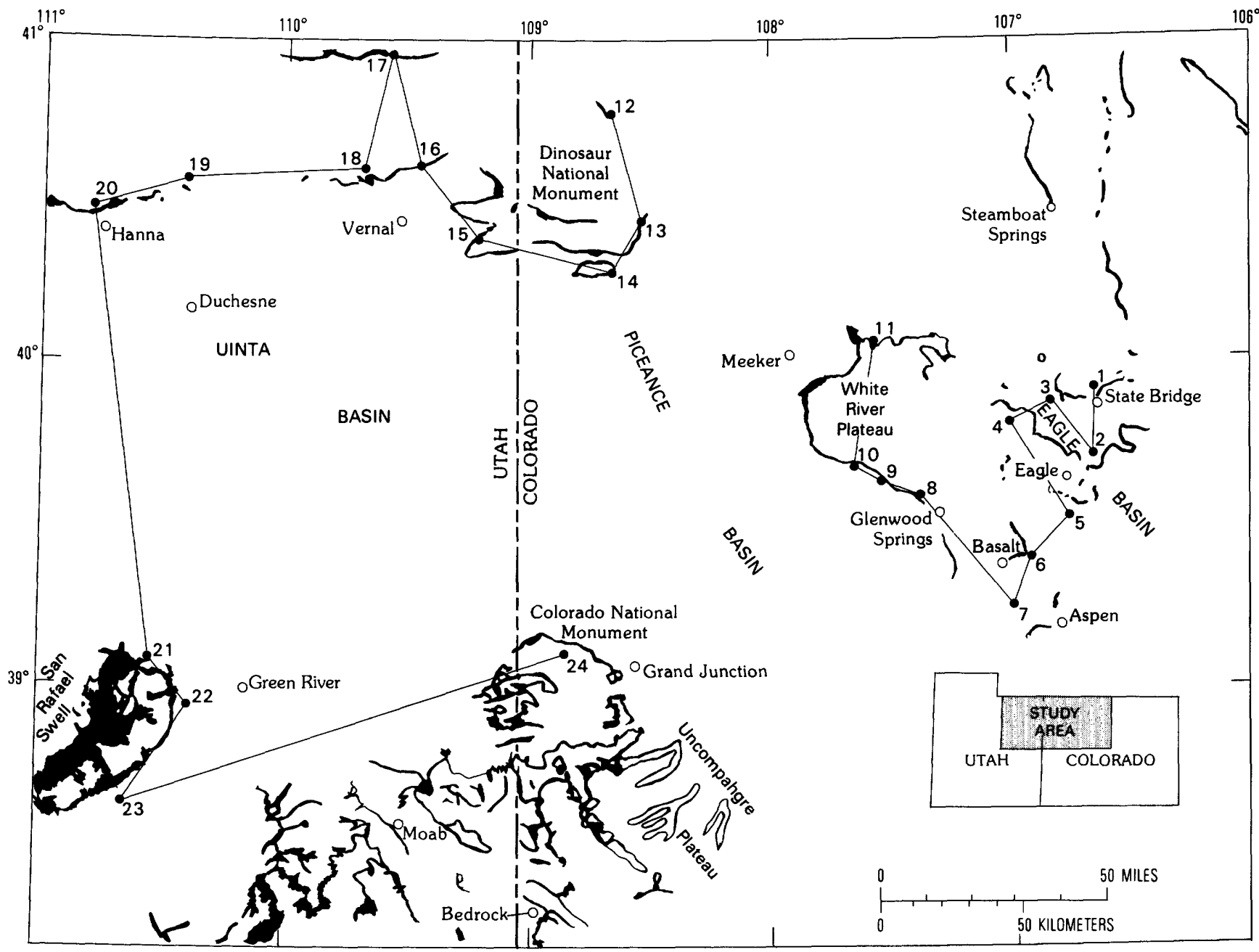

Figure 2. Map of the study area in northwestern Colorado and northeastern Utah showing geographic features, measured sections (numbered circles), and lines of cross sections referred to in text (see fig. 4). Outcrops of Chinle Formation shown in black. Modified from Stewart and others (1972) and Dubiel and Skipp (1989).

the Wyoming nomenclature to the Uinta Mountains area. Pipiringos (1968) described correlations and nomenclature of Triassic rocks in south-central Wyoming. Pipiringos and others (1969) discussed the stratigraphy of the Chinle Formation in north-central Colorado, just north of the Eagle basin. Pipiringos, in Segerstrom and Young (1972), described correlations of the Chinle and Popo Agie from north-central Colorado northward into Wyoming. Building on several earlier reports on Triassic stratigraphy, Stewart and others (1972) provided correlations and interpretations of depositional environments of the Chinle Formation and related Triassic strata throughout the Colorado Plateau and extended Chinle nomenclature into the Uinta Mountains in northeastern Utah and into northwestern Colorado.

Reports specifically describing the region of this report include several stratigraphic studies and only a few sedimentologic studies. Shropshire (1974) studied the stratigraphy and depositional environments of the Chinle and Jelm Formations in north-central Colorado. Red-bed formations near Aspen, Colorado, including the Chinle, were briefly described by Freeman and Bryant (1977). Principal Triassic unconformities of the Western Interior of the United States are summarized in Pipiringos and O'Sullivan (1978), along with a discussion of Triassic correlations relevant to the present study. Lupe $(1977,1979)$ interpreted depositional environments and measured stratigraphic sections of the Chinle in Utah from the San Rafael Swell to the Moab area. The sedimentology of the Upper Triassic Dolores Formation in southwestern Colorado, a correlative of the Chinle, was studied by Blodgett (1984, 1988). Lungfish burrows and possible freshwater crayfish burrows have been described from Chinle outcrops within the study area (Dubiel, Blodgett, and Bown, 1987, 1988, 1989; Hasiotis and Mitchell, 1989). Several reports discuss fossil fish (Schaeffer, 1967; Elliot, 1983, 1987) and the sedimentology and paleoecology of Chinle outcrops (Dubiel, Good, and Parrish, 1989; Parrish and others, in press) near Bedrock in western Colorado. 


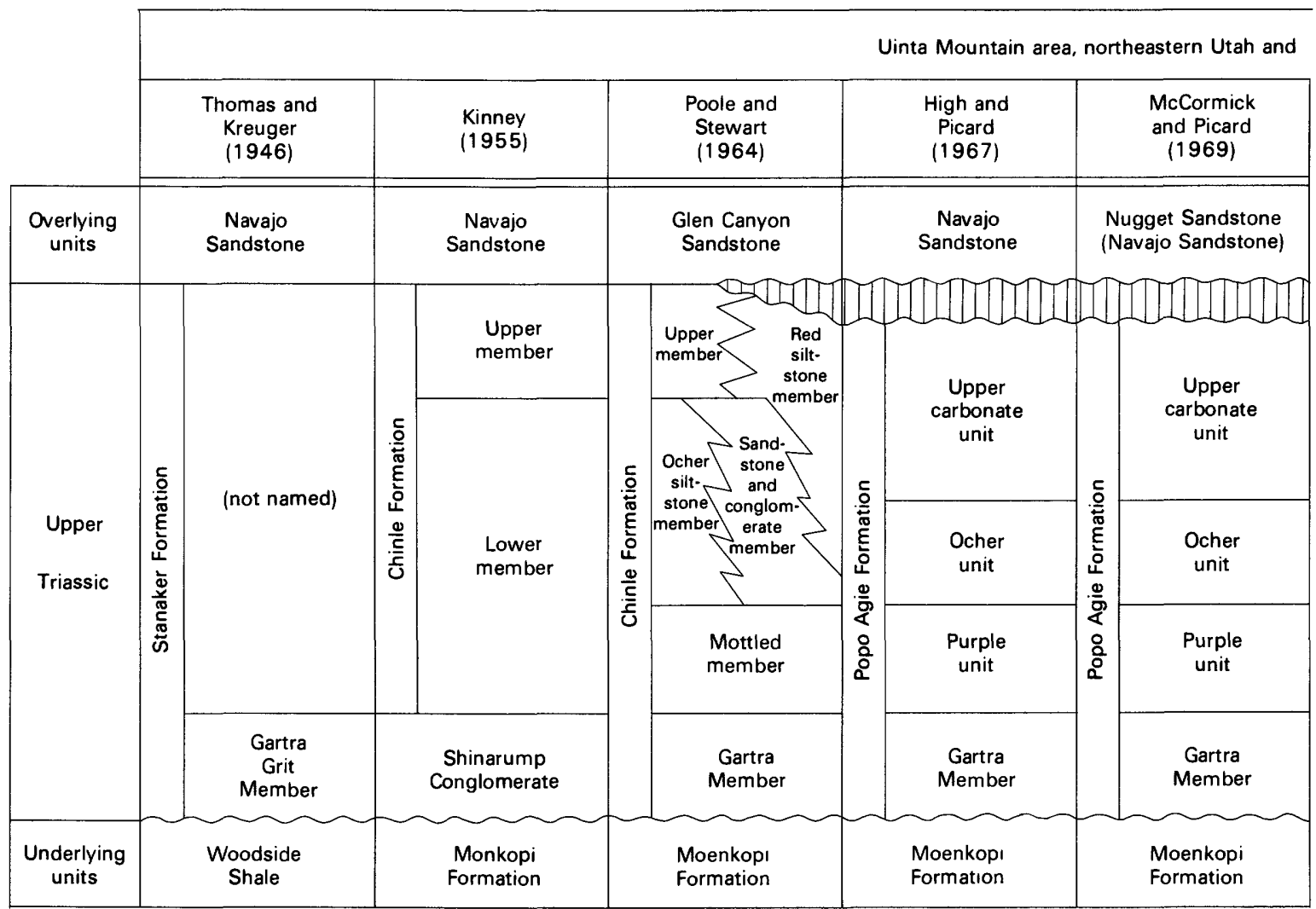

Figure 3 (above and facing page). Diagram showing correlation of stratigraphic nomenclature of Upper Triassic strata in Colorado, Utah, and Wyoming.

Dubiel and Skipp (1989) reported on preliminary stratigraphic and sedimentologic studies of the Chinle Formation in the Eagle basin of western Colorado.

\section{GEOLOGIC SETTING}

The ancestral Rocky Mountains, which included the ancestral Uncompahgre and Front Range highlands, were uplifted in the Pennsylvanian and Early Permian (for example, Mallory, 1972; Kluth and Coney, 1981) and continued to provide clastic detritus to the Chinle depositional basin during the Late Triassic (fig. 1). Paleozoic and Early Mesozoic sedimentary strata deposited adjacent to the uplifts were eroded, reworked, and incorporated into the Chinle.

In the Eagle basin, the Chinle Formation unconformably overlies the Pennsylvanian and Permian Maroon Formation, including the Permian Schoolhouse Member (previously called the Schoolhouse Tongue of the Weber Sandstone; Johnson and others, 1990), or the Permian and Triassic State Bridge Formation (Stewart and others, 1972; Tweto and others, 1978; Johnson, 1987; Dubiel and Skipp, 1989). On a regional scale, the unconformity is angular, in that the Chinle overlies progressively older strata in areas on or near the ancestral uplifts (Tweto and others, 1978). At Colorado National Monument, on the northeastern flank of the present Uncompahgre uplift, the Chinle unconformably overlies Precambrian crystalline rocks.

In the area around Dinosaur National Monument, in the Uinta Mountains of northeastern Utah and northwestern Colorado, and in the San Rafael Swell and near Moab in eastern Utah, the Chinle Formation rests unconformably on the Lower and Middle (?) Triassic Moenkopi Formation (Stewart and others, 1972; Pipiringos and O'Sullivan, 1978).

In the northern part of the study area, near the Uinta Mountains and Dinosaur National Monument, the Chinle Formation is unconformably overlain by an eolian unit that historically has been assigned to the Triassic (?) and Jurassic Nugget Sandstone (Pipiringos and O'Sullivan, 1978), or the Lower Jurassic Navajo Sandstone, or the Glen Canyon Sandstone. Recent work suggests that the lower part of this eolian unit is correlative with the Lower Jurassic Wingate Sandstone of the Glen Canyon Group farther to the south in the San Rafael Swell and near Moab (Peterson, 1988). Observations made during the present study indicate that the thin eolian unit immediately overlying the Chinle can be distinguished from an overlying eolian unit that is probably correlative with the Navajo Sandstone and the Nugget Sandstone. The results of the present study support Peterson's (1988) assignment of the lower thin eolian unit to the Wingate Sandstone. In the San Rafael Swell and near 


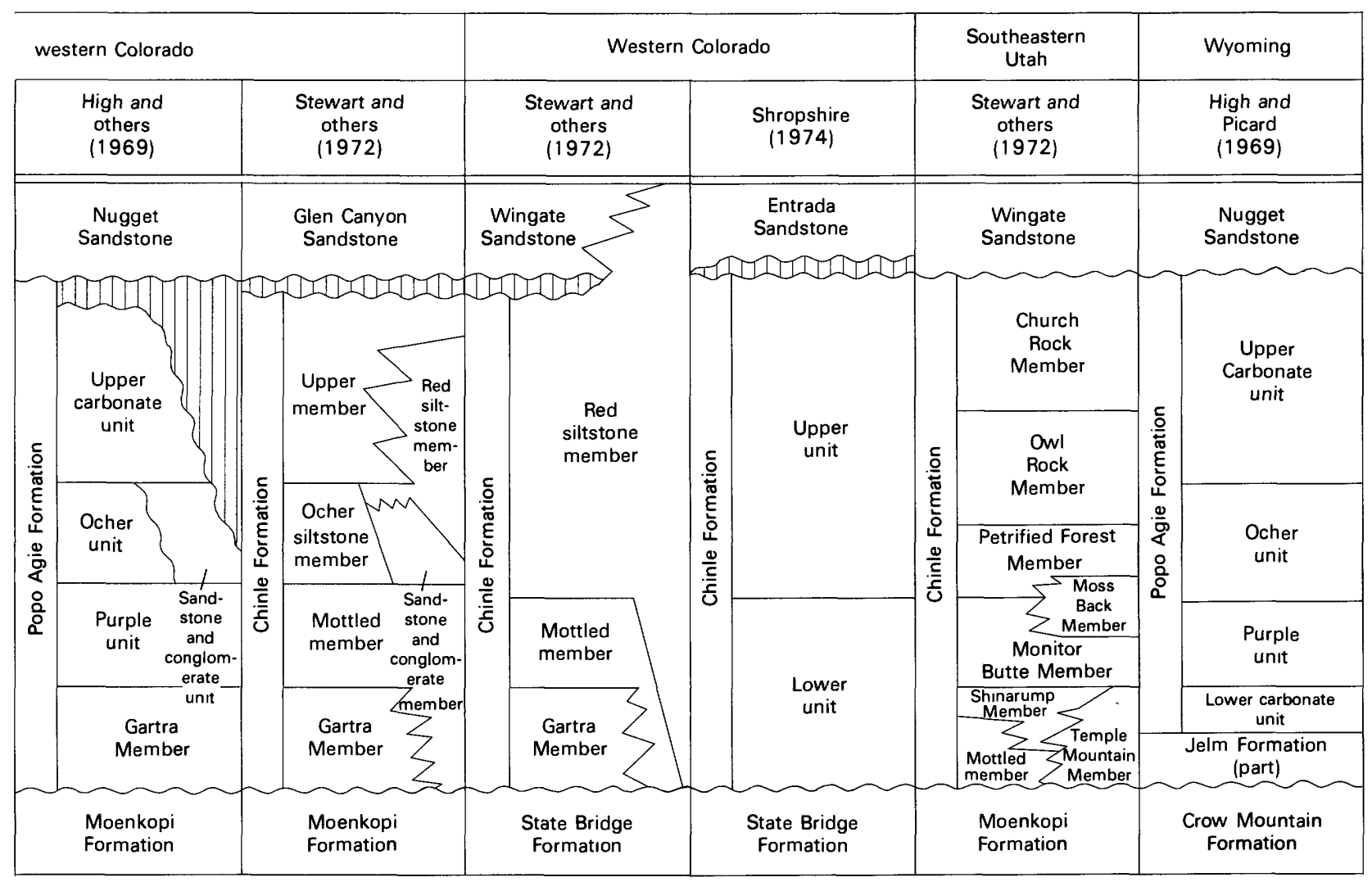

Moab, the Chinle is unconformably overlain by the Lower Jurassic Wingate Sandstone. In part of western Colorado, the Chinle is unconformably overlain by the Middle Jurassic Entrada Sandstone.

\section{STRATIGRAPHY}

Stratigraphy of the Chinle Formation in the large area encompassed by the present study is complicated by the designation of different formal and informal nomenclature by several workers for exposures in widely separated regions (fig. 3). Stewart and others (1972) summarized the stratigraphic nomenclature of the Chinle on the Colorado Plateau, and those designations are followed in this report. In the San Rafael Swell and near Moab, the Chinle consists, in ascending order, of the Temple Mountain Member, mottled member, and Shinarump, Monitor Butte, Moss Back, Petrified Forest, Owl Rock, and Church Rock Members. For the area around Moab, Blakey and Gubitosa (1983) applied the name Kane Springs strata to lateral facies equivalents of the Petrified Forest and Owl Rock Members.

The issue is complicated, however, with the application by some workers of the name Popo Agie Formation, which is used in Wyoming, for Upper Triassic strata in the Uinta Mountains (High and Picard, 1967; High and others, 1969; McCormick and Picard, 1969). Despite the discrepancy over whether the rocks are assigned to the
Chinle Formation or the Popo Agie Formation, informally designated stratigraphic units and their lateral and vertical relations around the Uinta Mountains are common to each of the reports (fig. 3). The descriptive informal names of the subdivisions are virtually identical in each report. The Gartra Member is generally accepted in each report as the conglomeratic sandstone at the base of the Chinle or Popo Agie, although Kinney (1955) termed this unit the Shinarump Conglomerate. Overlying the Gartra is either a mottled member or a purple unit, clearly referring to the same stratigraphic unit. Shropshire (1974) provided the only significant deviation from this scheme, grouping the basal conglomerates and the mottled units directly above them into the lower unit and the remainder of the Chinle into an upper unit (fig. 3). As discussed in the sedimentology section later in this report, Shropshire's subdivisions have some validity because the present study interprets the mottled coloration to be the result of pedogenic or early diagenetic alteration that affected both the Gartra and the overlying siltstones and mudstones.

Above the Gartra Member, one or more fine-grained units of the Chinle Formation is recognizable as distinct lithostratigraphic units, and they have similar informal names (fig. 3). In northwestern Colorado, the red siltstone member constitutes the entire upper Chinle. In the eastern part of Dinosaur National Monument, the middle part of the Chinle contains a sandstone and conglomerate member that interfingers with the overlying red siltstone member and the 
equivalent ocher siltstone member. The middle part of the Chinle is overlain and interfingers with the upper member, also referred to as the upper carbonate unit. Each of these previously named units or members was recognized in the present study, and the general stratigraphic relations are supported by the sedimentology study.

The relationship between the Chinle Formation and the various overlying rocks that are referred to as the Nugget Sandstone, Navajo Sandstone, Glen Canyon Sandstone, or Wingate Sandstone has been described as interfingered, unconformable, or an angular unconformity (fig. 3). The present study indicates that in the Uinta Mountains and in Dinosaur National Monument the Chinle Formation is unconformably overlain by eolian sandstones equivalent to the Lower Jurassic Wingate Sandstone, which unconformably overlies the Chinle in the San Rafael Swell and near Moab. Peterson (1988) assigned the eolian sandstone overlying the Chinle in the Uinta Mountains and around Dinosaur National Monument to the lower part of the Nugget Sandstone and stated that it is equivalent to the Wingate Sandstone farther to the south in Utah. Observations on grain size, lithology, and bedding made in the present study indicate that the eolian rocks unconformably overlying the Chinle in the Uinta Mountains can be subdivided into two distinct eolian units. The lower eolian unit is thin (10-30 ft, 3-10 m) and probably is equivalent to the Wingate Sandstone, whereas the upper eolian unit is much thicker and lighter in color and probably correlates with the Navajo Sandstone, supporting Peterson's (1988) conclusions. In western Colorado, the Chinle is unconformably overlain by eolian strata of the Middle Jurassic Entrada Sandstone. Despite the large-scale angular unconformity indicated by these regional relationships, on a local scale beds appear conformable, and there appears to be no angular unconformity between the Popo Agie and the overlying Nugget Sandstone as reported by High and others (1969) and Picard (1975). The contact shown in photographs of those reports most likely depicts a diastem within Chinle strata typical of a crevasse splay or lacustrine delta rather than an angular contact between the Chinle and the Nugget.

\section{SEDIMENTOLOGY}

In the study area, the Chinle Formation consists of as much as $1,000 \mathrm{ft}(300 \mathrm{~m})$ of predominantly dark-reddishbrown to moderate-reddish-orange, fine-grained sandstone, siltstone, and mudstone and lesser amounts of dark-gray to reddish-purple conglomeratic sandstone, limestone-pebble conglomerate, sandstone, and gray limestone. Stratigraphic sections of the Chinle Formation (fig. 4, table 1) were measured to record data on composition, color, grain size, bedding, physical sedimentary structures, and lithosome geometry. These data and additional observations on paleosols and biogenic sedimentary structures, including trace fossils and rhizoliths, were utilized to designate lithofacies in the Chinle. Lithofacies then were grouped into lithofacies assemblages on the basis of rock type, lithosome geometry, sedimentary structures, fauna and flora, and repetition of the sequences. Each lithofacies assemblage represents a particular depositional environment (fig. 4).

This study utilized the concept of lithofacies analysis, rather than the traditional descriptive approach of lithostratigraphy, to decipher the depositional history of the Chinle in the Uinta, Piceance, and Eagle basins. Because of the lack of physical and biostratigraphic markers in the continental rocks of the Chinle, the lithofacies approach was deemed more suitable for correlating measured sections and for interpreting the succession of depositional environments and depositional history. Sections are not hung on a specific horizontal datum because no such datum exists within the Chinle to correlate definitively the laterally variable continental depositional facies. Because unconformities mark both the lower and upper contacts of the Chinle, those horizons also do not provide suitable datums for correlating Chinle strata. The method employed herein utilizes facies concepts and the application of Walther's Law, together with facies relations provided by sedimentologic studies of ancient and modern continental systems (for example, Reading, 1978; Miall, 1984), to make reasonable correlations of Chinle lithofacies assemblages (fig. 4). Where available, beds and units that can be identified from section to section were used as local stratigraphic markers. Because strata change facies in several areas, individual beds may not correlate precisely between sections; the lithofacies assemblages and transitions shown, however, provide the most reasonable and accurate correlations possible for depicting the Chinle depositional system.

\section{Lithofacies and Depositional Environments}

The lower part of the Chinle Formation fills local scours and large swales eroded into the underlying rocks. The contact is generally sharp and irregular, but it is difficult to pick in places where conglomeratic units of the Chinle overlie compositionally similarly conglomeratic strata of the Maroon or State Bridge Formations. The upper part of the Chinle is characterized by a variety of lithofacies that includes several lithologies and associated biogenic and physical sedimentary structures. The following lithofacies assemblages were designated to describe the different depositional environments of the Chinle in the study area (fig. 4).

\section{Valley-Fill and Active Channel-Fill Deposits}

The basal part of the Chinle Formation consists of as much as $60 \mathrm{ft}(18 \mathrm{~m})$ of gray to yellow and dark- 
reddish-brown or dark-reddish-purple conglomerate, conglomeratic sandstone, and sandstone containing pebbles of quartz, granite, and gneiss as large as $4.5 \mathrm{in} .(11 \mathrm{~cm})$ in diameter (fig. 5). Freeman (1971) reported $388 \mathrm{ft}(117 \mathrm{~m})$ of a unit he termed the "coarse unit of Toner Creek" of the State Bridge Formation. In the same area near Toner Creek, S.Y. Johnson (U.S. Geological Survey, written commun., 1989) measured about $170 \mathrm{ft}(52 \mathrm{~m})$ of conglomerate that he believed correlates with Freeman's unit but that should be assigned to the Chinle. It was not possible to corroborate this observation at Toner Creek during the present study. Conglomeratic units are medium to thick bedded and exhibit medium- to large-scale trough and planar crossbeds, or they are massive. Sandstone strata are coarse to fine grained, are thin to medium bedded, and contain planar and trough crossbeds, climbing-ripple laminations or horizontal laminations. In general, both the grain size and the scale of the sedimentary structures decrease upward within this unit.

Conglomeratic units at the base of the Chinle are generally assigned to the Gartra Member in northwestern Colorado and northeastern Utah and to the Temple Mountain and Shinarump Members in the San Rafael Swell. At Derby Junction (figs. 3, 4), the Gartra contains blocks of eolian sandstone from the underlying State Bridge Formation that are as large as $1.5 \mathrm{ft}(0.5 \mathrm{~m})$, indicating lithification of the underlying strata prior to erosion and redeposition within the Chinle. At East Brush Creek (figs. 3, 4), the Gartra contains clasts of silicified wood that are as long as $2 \mathrm{ft}(0.6 \mathrm{~m})$. Plots of the maximum pebble size in the Gartra Member (Shropshire, 1974), coupled with data on pebble sizes in basal units of the Chinle from the present study, indicate a general decrease in maximum size of siliciclastic pebbles toward the northwest and away from the area of the ancestral Uncompahgre and Front Range uplifts. The size distribution and composition of the clasts indicate a highland source for the clasts. Paleocurrent indicators in the Gartra (Stewart and others, 1972; Shropshire, 1974) suggest that deposition was generally away from the bounding uplifts and toward the northwest into the Uinta, Piceance, and Eagle basins.

The grain size, sedimentary structures, and overall geometry of coarse-grained deposits in the Gartra, Temple Mountain, and Shinarump Members resemble those described for modern and ancient fluvial sequences (for example, Allen, 1965a, b; Harms and others, 1975). The massive conglomeratic and planar crossbedded sandstones represent fluvial bedload deposition. The large variations in thickness observed on outcrops and between measured sections, and the erosional contact with significant relief cut into underlying units, indicate that the basal conglomerates are valley fills. The grain size and sedimentary structures suggest that deposition was by fluvial systems on in-channel bars (Rust, 1978). The upward transition to finer grained sandstone containing trough crossbedding and horizontal and climbing-ripple laminations reflects fluvial bedload deposition by migrating dunes, ripples, and plane beds (Jackson, 1976).

The upper part of the Gartra Member, the lower part of the overlying red siltstone member, and the Temple Mountain Member of the Chinle Formation (fig. 3) are locally mottled purple and white (fig. 6). In western Colorado, these mottled strata were termed the mottled member by Stewart and others (1972), but Shropshire (1974) included the mottled rocks along with the Gartra in his lower unit of the Chinle. The present study recognizes a gradational contact between the Gartra Member and the mottled strata and a gradational contact between the mottled strata and the overlying red units of the Chinle. In places, each unit intertongues with the others. There is a gradual change in grain size and sedimentary structures upward through the units that reflects a transition of depositional environments. In the San Rafael Swell, mottled strata of the Temple Mountain Member generally underlie the Shinarump Member, but, locally in the San Rafael Swell, mottled strata are present stratigraphically higher in the Chinle.

The mottled coloration of these units is thought to reflect alteration and translocation of iron-bearing minerals in the rocks, similar to the purple mottled unit of the Monitor Butte Member of the Chinle Formation in southeastern Utah (Dubiel, 1987a, b, c). Many of the mottled units contain ubiquitous, large-diameter, cylindrical trace fossils interpreted as lungfish burrows (fig. 6) (Dubiel, Blodgett, and Bown, 1987, 1988, 1989) and as freshwater crayfish burrows (Hasiotis and Mitchell, 1989). The mottles probably represent relocation of iron due to fluctuating water tables penecontemporaneous with deposition; thus, the strata represent a gleyed paleosol. Both the mottles and the long trace fossils reflect fluctuating water tables. A similar interpretation is proposed for the development of the mottled coloration in the Gartra Member and the Temple Mountain Member and associated rocks in this study.

\section{Lateral-Accretion Deposits}

The largest part of the upper part of the Chinle Formation overlying the conglomerates and sandstones of the Gartra, the Shinarump, and the Temple Mountain Members consists almost entirely of dark-reddish-brown to reddish-orange, very fine to fine grained, thin- to thickbedded sandstone, siltstone, and mudstone. The finegrained units are assigned to the red siltstone member in the Eagle basin, to the red siltstone member and the upper member or unit in the Uinta Mountains and near Dinosaur National Monument, and to the Moss Back and the Church Rock Members in the San Rafael Swell and near Moab (figs. 2, 3). 


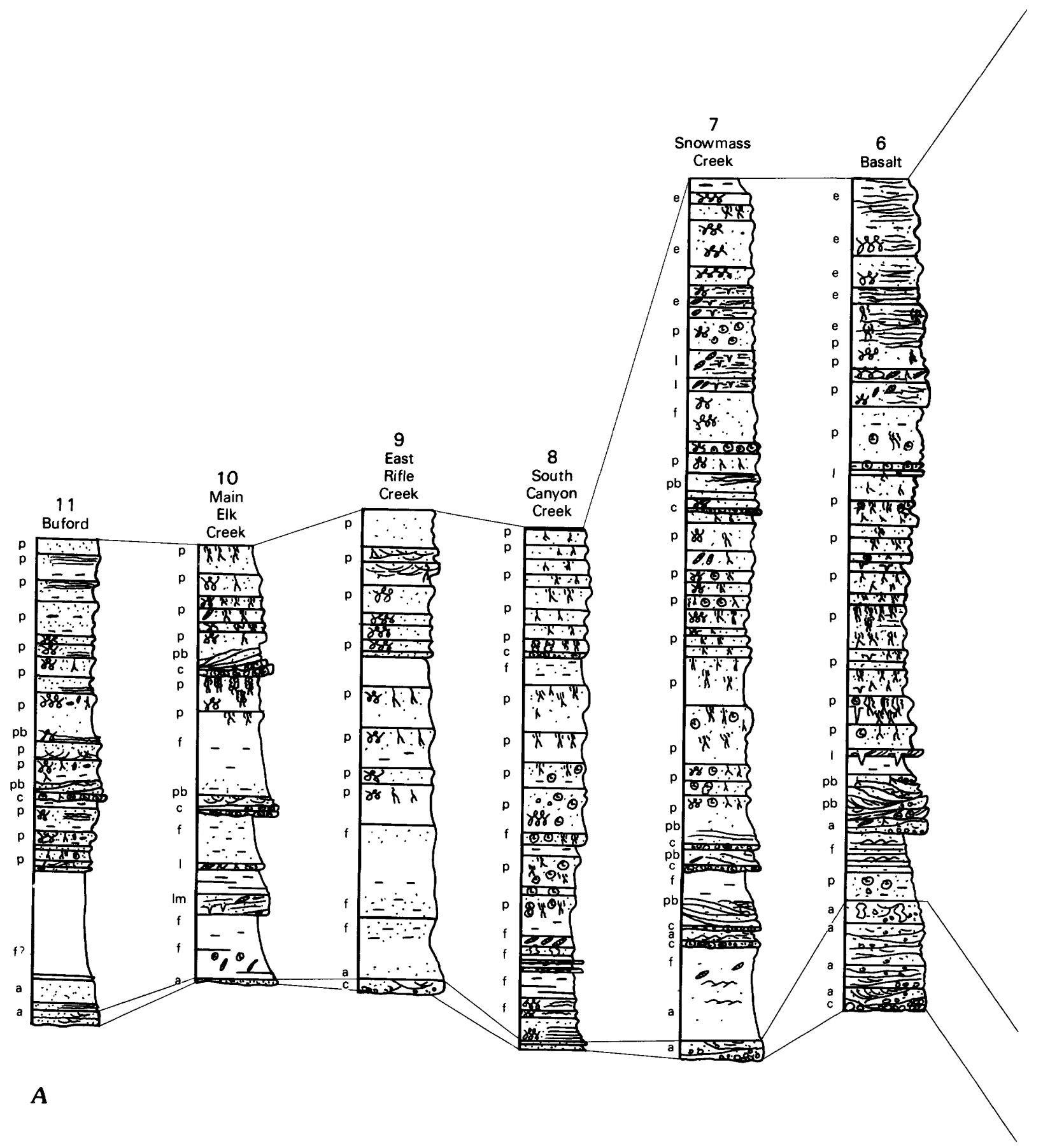

Figure 4 (above and following pages). Measured stratigraphic sections of the Upper Triassic Chinle Formation. Lines of section shown on figure 2 . Sections show lithofacies, depositional environments, and stratigraphic units. $A$, Cross section of Chinle Formation in the Eagle basin. B, Cross section across the Uinta Mountains to the San Rafael Swell.

The red strata can be assigned to two distinct lithofacies, referred to as lateral-accretion deposits and floodplain deposits (discussed in the next section). The lateral-accretion deposits are characterized by large-scale cross-stratification, whereas the floodplain deposits are dominantly massive to horizontally bedded. The lateralaccretion deposits contain sets of large-scale, epsilon cross- stratification (ECS) (Allen, 1963, 1965a, b) (fig. 7). Within the sets, the lithology grades upward from gray to reddishgray, limestone- and siltstone-pebble conglomerate and quartzose sandstone at the base, through reddish-brown, interbedded sandstone, siltstone, and mudstone, to dominantly reddish-brown siltstone and mudstone at the top. Individual strata within the ECS are thin to thick 


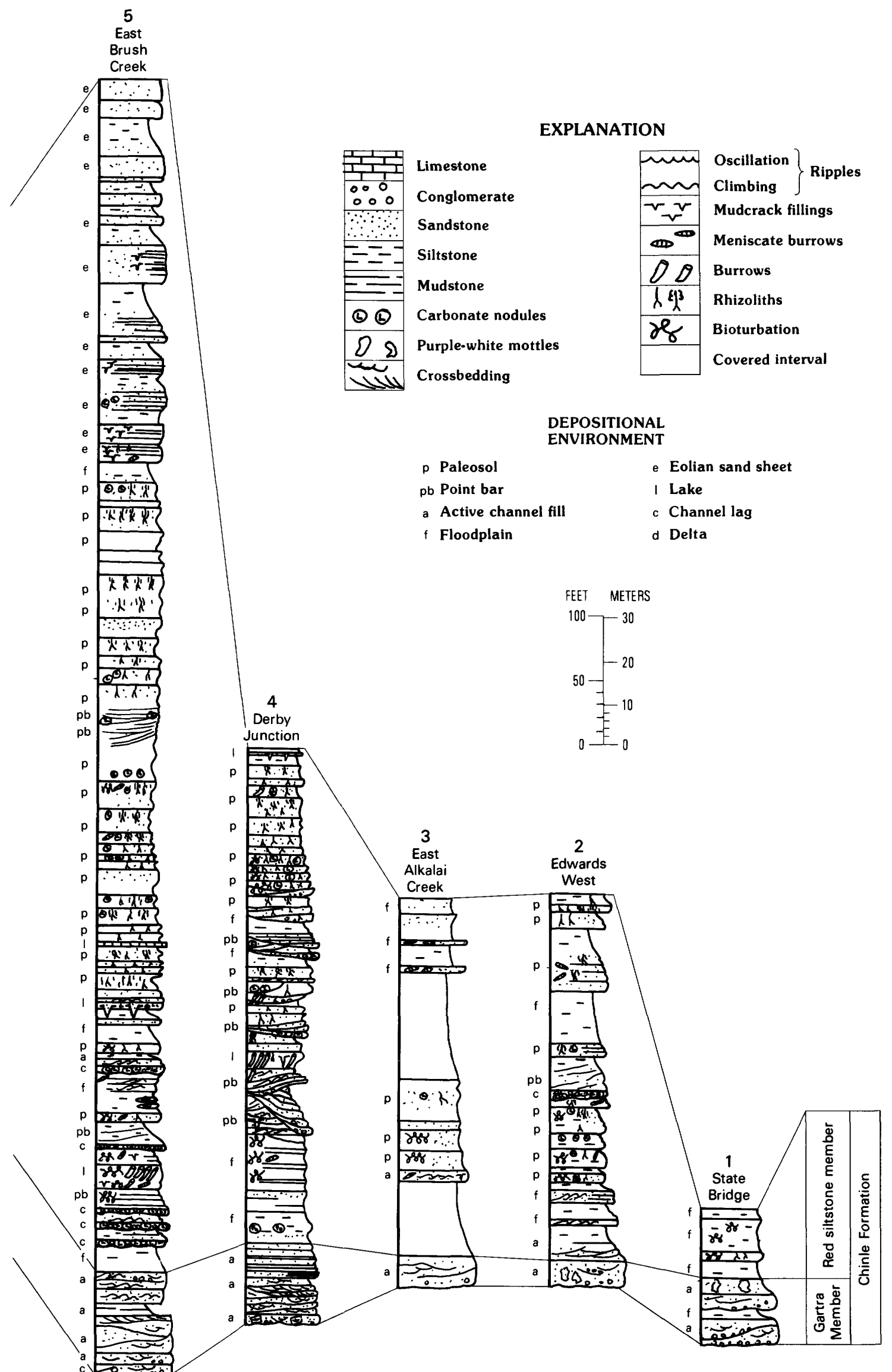




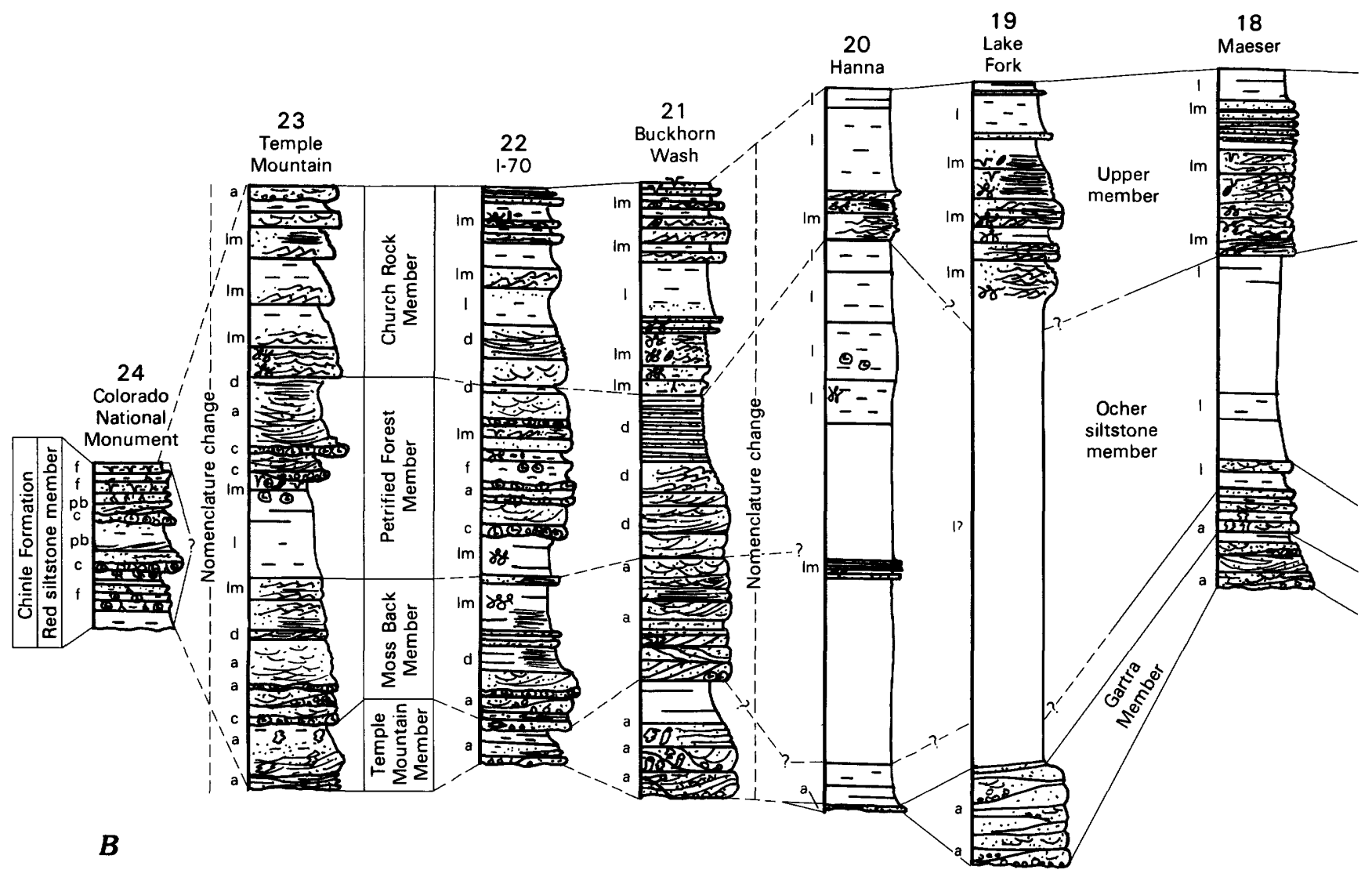

bedded and dip as much as $10^{\circ}-15^{\circ}$. Internally, the beds of the ECS contain small-scale trough and ripple crossstratification with trough axes oriented oblique or perpendicular to the dip of the ECS. ECS sets are as thick as $12 \mathrm{ft}(3.7 \mathrm{~m})$, and locally sets are superposed. Generally, the ECS units can be traced laterally into horizontally bedded strata described in the following section as overbank floodplain deposits.

The large-scale epsilon cross-stratification is interpreted as lateral-accretion stratification (LAS) (Allen, $1965 \mathrm{~b}$ ), because the trend of the small-scale sedimentary structures within the units indicates that flow was across the dip of the ECS. The interbedded sandstone, siltstone, and mudstone of the LAS are interpreted as point bars that resulted from helical channel flow in moderately to highly sinuous fluvial systems, and the finer grained deposits at the top of the sequences represent deposition by waning currents in abandoned channels and oxbow lakes (MoodyStuart, 1966; Jackson, 1976). The predominantly fine grain size of the strata and the carbonate clasts indicate a mixedto suspended-sediment load in the fluvial system. The limestone-pebble conglomerate at the base of the LAS represents the basal channel lags of the fluvial system. The carbonate clasts are intraformational, derived from calcic paleosols developed on floodplain deposits described in the following section. The carbonate pebbles also represent the largest clasts available to the streams and suggest a lack of siliciclastic pebbles in the source area of the streams or a lack of shear velocity to transport them.

Point-bar deposits in the Chinle Formation are common in the red siltstone member of the Eagle basin (fig. $4 A$ ) and also have been reported from the Chinle Formation near Bedrock, Colorado. (Dubiel, Good, and Parrish, 1989), and the equivalent Dolores Formation on the western flank of the Uncompahgre Plateau (Blodgett, 1984, 1988, 1990). Low-gradient, moderate- to high-sinuosity fluvial systems developed on both sides of the ancestral Uncompahgre uplift subsequent to filling of paleovalleys by coarsegrained fluvial deposits of the Gartra Member. These meandering fluvial systems dominated Chinle deposition in the Eagle basin as proximal depositional systems that supplied sediment to depositional settings to the northwest. The point-bar deposits are virtually nonexistent in outcrops examined in the Uinta Mountains and near Dinosaur National Monument and are rare in the San Rafael Swell sections measured for this study (fig. $4 B$ ).

\section{Floodplain Deposits}

A large part of the upper Chinle Formation is composed of dark-reddish-brown to reddish-orange, massive to horizontally stratified, thin- to thick-bedded 


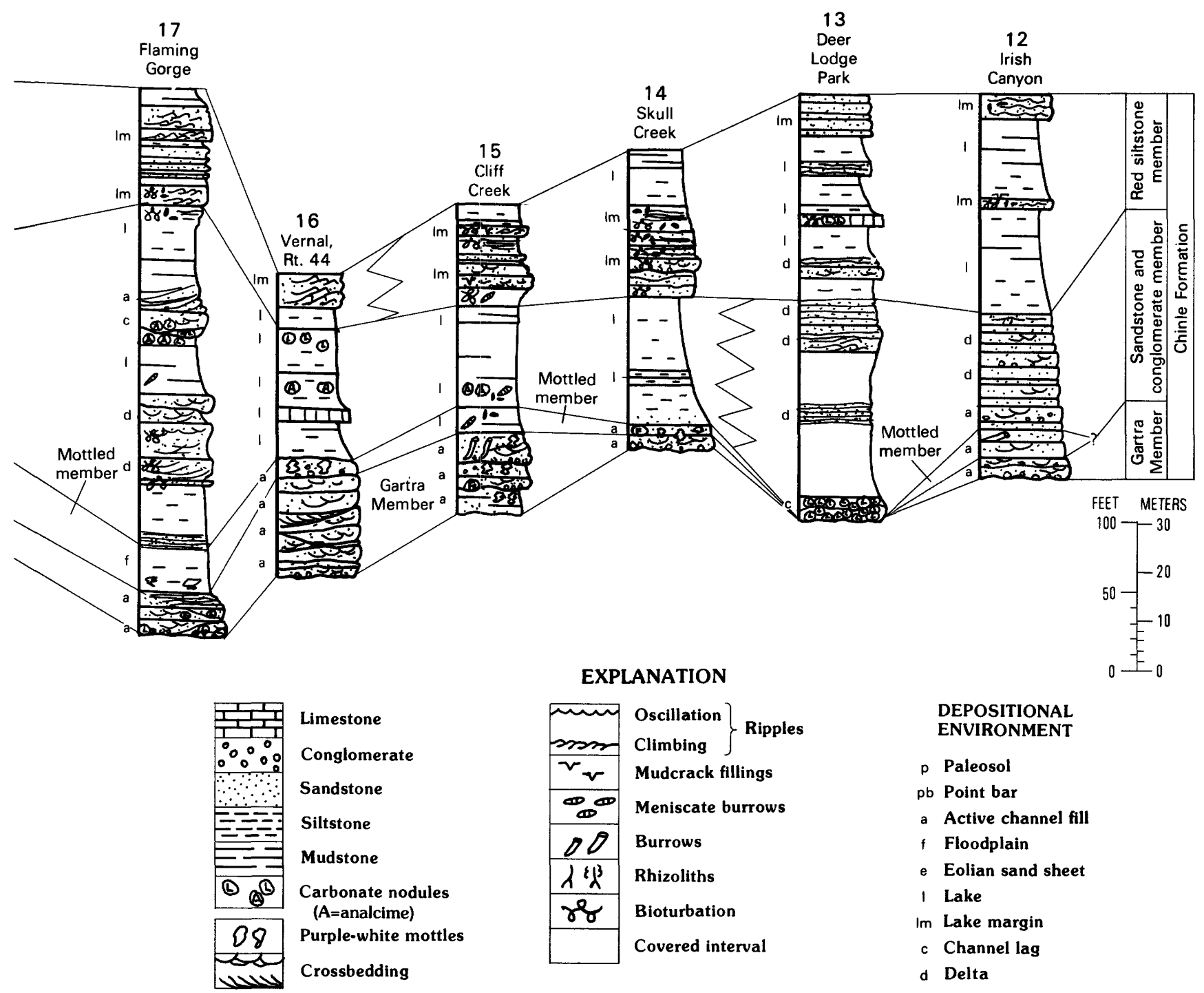

mudstone, siltstone, and fine-grained sandstone (fig. 8). Locally, the flat-lying strata can be traced laterally into the lateral-accretion deposits described in the preceding section of this report. Individual beds are laterally extensive, but substantial cover between measured sections precludes tracing individual beds more than a few hundred yards. Locally, the beds are directly adjacent to lateral-accretion deposits, forming cutbanks eroded during lateral migration of the sinuous fluvial system. The strata form the cut bank of the outside bend of the meandering stream deposits. At these localities, the strata contain abundant, superposed and intersecting sand-filled desiccation cracks (fig. 9). The abundance and intersecting nature of the cracks indicate many episodes of channel-overbank flooding and subsequent desiccation. Internally, the beds are very uniform in grain size and exhibit few physical sedimentary structures, but they do display abundant evidence of pedogenic modification and biogenic structures that provide critical information for interpreting their genesis.
The horizontally stratified strata contain indurated, isolated or coalesced carbonate nodules and several types of rhizoliths, or plant-root trace fossils, and invertebrate trace fossils. Carbonate nodules are present as single, isolated carbonate glaebules as large as 2 in. $(5 \mathrm{~cm})$, as coalesced nodules, or as laterally extensive coalesced nodular beds. The arrangement of the carbonate from isolated nodules to coalesced nodular beds corresponds to carbonate accumulations designated as Stage I to Stage IV by Gile and others (1966). Nodule formation penecontemporaneous with sedimentation and nodule induration prior to transport are indicated by the abundance of similar carbonate nodules as clasts elsewhere in fluvial deposits in the Chinle.

Several attributes of the carbonate nodules suggest that their early development in the Chinle was the result of pedogenic accumulation of carbonate. Virtually all of the nodules in a single bed are similar in size and distribution; however, beds of similar lithology and grain size immediately below or above may contain nodules of either 
Table 1. Locations of measured sections of the Chinle Formation in the Uinta, Piceance, and Eagle basins, northwestern Colorado and northeastern Utah

[Location of section shown by number on figures 2 and 4]

\begin{tabular}{lc}
\hline Measured section number and name & $\begin{array}{c}\text { Location } \\
\text { (sec., township, range) }\end{array}$ \\
\hline 1. State Bridge & $24,2 \mathrm{~S} ., 83 \mathrm{~W}$. \\
2. Edwards West & $35,4 \mathrm{~S} ., 83 \mathrm{~W}$. \\
3. East Alkalai Creek & $21,2 \mathrm{~S} ., 84 \mathrm{~W}$. \\
4. Derby Junction & $31,2 \mathrm{~S} ., 85 \mathrm{~W}$. \\
5. East Brush Creek & $7,6 \mathrm{~S} ., 83 \mathrm{~W}$. \\
6. Basalt & $5,8 \mathrm{~S} ., 86 \mathrm{~W}$. \\
7. South Canyon Creek & $2,6 \mathrm{~S} ., 90 \mathrm{~W}$. \\
8. Snowmass Creek & $26,8 \mathrm{~S} ., 86 \mathrm{~W}$. \\
9. East Rifle Creek & $34,4 \mathrm{~S} ., 92 \mathrm{~W}$. \\
10. Main Elk Creek & $15,5 \mathrm{~S} ., 91 \mathrm{~W}$. \\
11. Buford & $19,1 \mathrm{~S} ., 92 \mathrm{~W}$. \\
12. Irish Canyon & $30,10 \mathrm{~N} ., 100 \mathrm{~W}$. \\
13. Deerlodge Park & $21,6 \mathrm{~N} ., 99 \mathrm{~W}$. \\
14. Skull Creek & $31,4 \mathrm{~N} ., 100 \mathrm{~W}$. \\
15. Cliff Creek & $21,5 \mathrm{~N} ., 24 \mathrm{E}$. \\
16. Vernal & $5,2 \mathrm{~N} ., 22 \mathrm{E}$. \\
17. Flaming Gorge & $8,2 \mathrm{~N} ., 109 \mathrm{~W}$. \\
18. Maeser & $18,2 \mathrm{~N} ., 21 \mathrm{E}$. \\
19. Lake Fork & $34,2 \mathrm{~N} ., 5 \mathrm{~W}$. \\
20. Hanna & $3,1 \mathrm{~S} ., 8 \mathrm{~W}$. \\
21. Buckhorn Wash & $11,20 \mathrm{~S} ., 11 \mathrm{E}$. \\
22. I-70 & $12,22 \mathrm{~S} ., 13 \mathrm{E}$. \\
23. Temple Mountain & $35,24 \mathrm{~S} ., 11 \mathrm{E}$. \\
24. Colorado National Monument-North & $32,1 \mathrm{~N} ., 2 \mathrm{~W}$. \\
\hline &
\end{tabular}

lesser or greater size and abundance, but again with similar size and distribution within that bed. The implication is that the process responsible for nodule formation was selectively operating to different degrees on individual beds of similar lithology and texture.

Other specific attributes of the carbonate accumulations closely resemble pedogenic accumulation of carbonate in certain types of modern soils and published examples of ancient paleosols (Wright, 1982). The carbonate in some Chinle beds is present as closely packed, vertically oriented, prismatic columns as much as 1 in. (2.5 $\mathrm{cm}$ ) in diameter and 6-8 in. $(15-20 \mathrm{~cm})$ long. Other beds contain accumulations of nodules oriented along concaveupward, intersecting fractures localized near the tops of beds (fig. 10). These features closely resemble pseudoanticlines described by Allen (1974) for the Old Red Sandstone and also closely resemble gilgai or moundlike microrelief produced by carbonate accumulation and repeated wetting and drying of clay-rich soils, or vertisols, in modern tropical settings (Young, 1976). Similar vertic paleosols containing carbonate nodules have been described for the Upper Triassic Dolores Formation in southwestern Colorado (Blodgett, 1984, 1988, 1990).
The lateral relation of these horizontally stratified beds to fluvial point-bar deposits, the early formation and induration of carbonate nodules in the beds, and the association of these nodules with alteration haloes interpreted below as plant-root trace fossils indicate that this lithofacies represents floodplain deposits lateral to Chinle meandering fluvial systems. The floodplain deposits were pedogenically modified and represent calcic and vertic paleosols, expressed as isolated carbonate nodules, pseudoanticlines, and abundant intersecting and superposed desiccation cracks. The induration of the carbonate nodules within the soil profiles and the superposed desiccation cracks both suggest extensive and repeated drying of the floodplains.

The floodplain lithofacies contains several types of ichnofossils, including rhizoliths or plant-root trace fossils (Klappa, 1980), invertebrate trace fossils, and largediameter $(4 \mathrm{in.}, 10 \mathrm{~cm}$ ) trace fossils attributed to either lungfish or freshwater crayfish. There are three types of rhizoliths in the floodplain facies (Dubiel, 1988). The first type, root alteration haloes, are dark-reddish-purple, vertical, cylindrical alteration mottles that formed around plant roots that grew in Chinle time. Locally the root alteration haloes taper and bifurcate downward and grade into finer rootlet traces (fig. 11). The second type of rhizolith, called rhizotubules, consists of alteration haloes surrounded by localized carbonate nodules that are stacked parallel to the vertical axis of the halo. The less cemented interiors of the haloes weather out, leaving the moldic interior. Rhizocretions, the third type of rhizolith, are formed by stacked carbonate nodules that coalesce and completely encase the root alteration halo. The increased carbonate cementation in the rhizocretions indicates that more time was available in distal floodplain settings to accumulate more carbonate cement in the paleosols (Bown and Kraus, 1987). The interpretation of rhizoliths supports the contention that these strata represent pedogenically modified floodplain deposits lateral to Chinle fluvial systems.

Several types of trace fossils are present in the floodplain lithofacies. Large-diameter $(4 \mathrm{in} ., 10 \mathrm{~cm}$ ) trace fossils, interpreted as lungfish burrows or the trace of freshwater decapod crustaceans (Dubiel, Blodgett, and Bown, 1987, 1988, 1989; Hasiotis and Mitchell, 1989; Hasiotis and Dubiel, in press), are locally very abundant. Smaller diameter trace fossils commonly are present with the larger traces and locally with the rhizoliths. The small ichnofossils are sinuous and cylindrical, about $1 / 4$ in. $(0.6 \mathrm{~cm})$ in diameter. The traces do not branch but do interpenetrate. Internally, very fine, concave backfills are accentuated by alternating hematite-rich and hematite-poor meniscae. These backfilled trace fossils are interpreted as endichnial burrows belonging to the ichnogenus Muensteria sp., on the basis of meniscate backfill without apparent wall structure. Assignment to that ichnogenus solely on those 


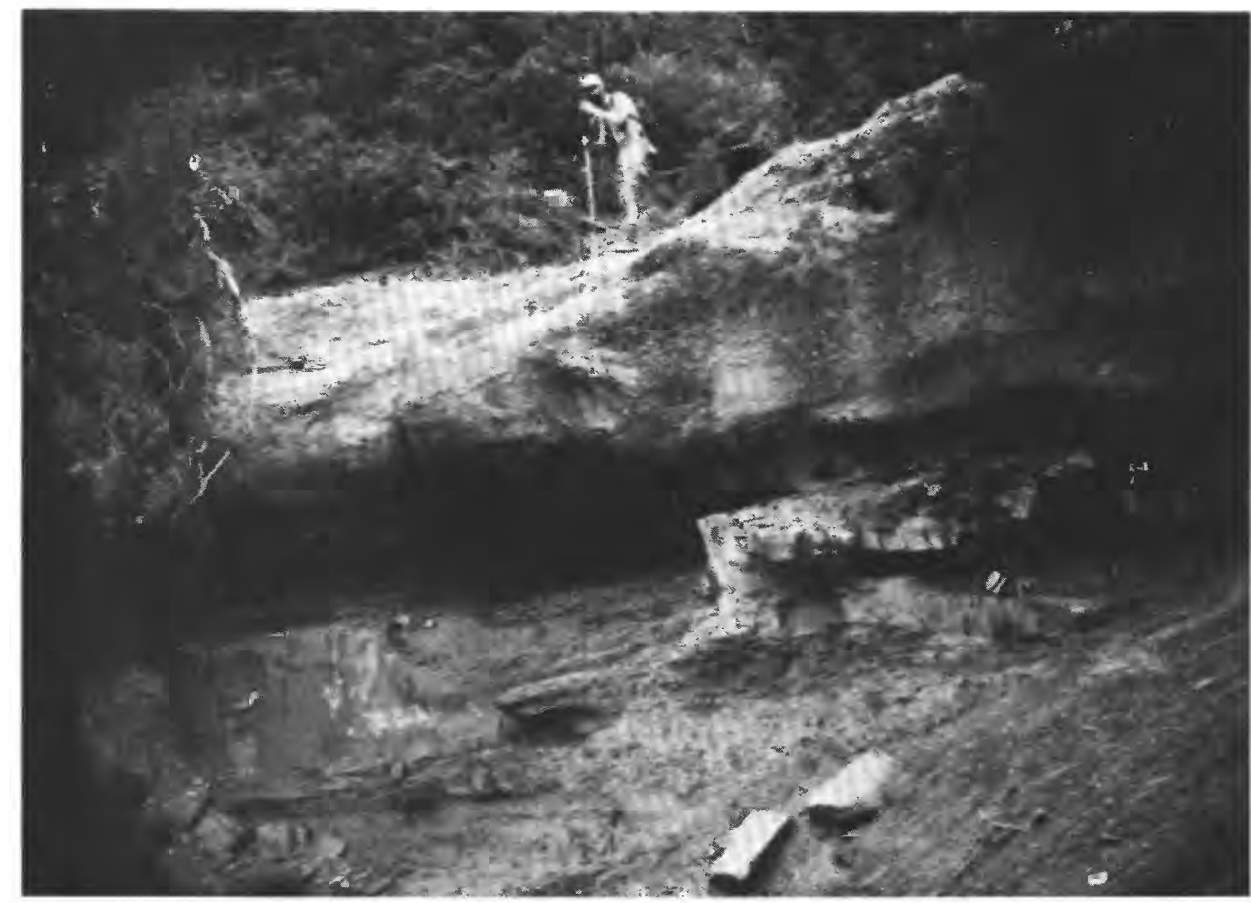

Figure 5. Fluvial valley-fill conglomerate and sandstone of the Gartra Member at base of the Chinle Formation near Basalt, Colorado. Ledge-forming Gartra Member unconformably overlies eolian dune deposits within the Sloan Peak Member of the State Bridge Formation. Geologist with $5-\mathrm{ft}(1.5 \mathrm{~m})$ staff on ledge.

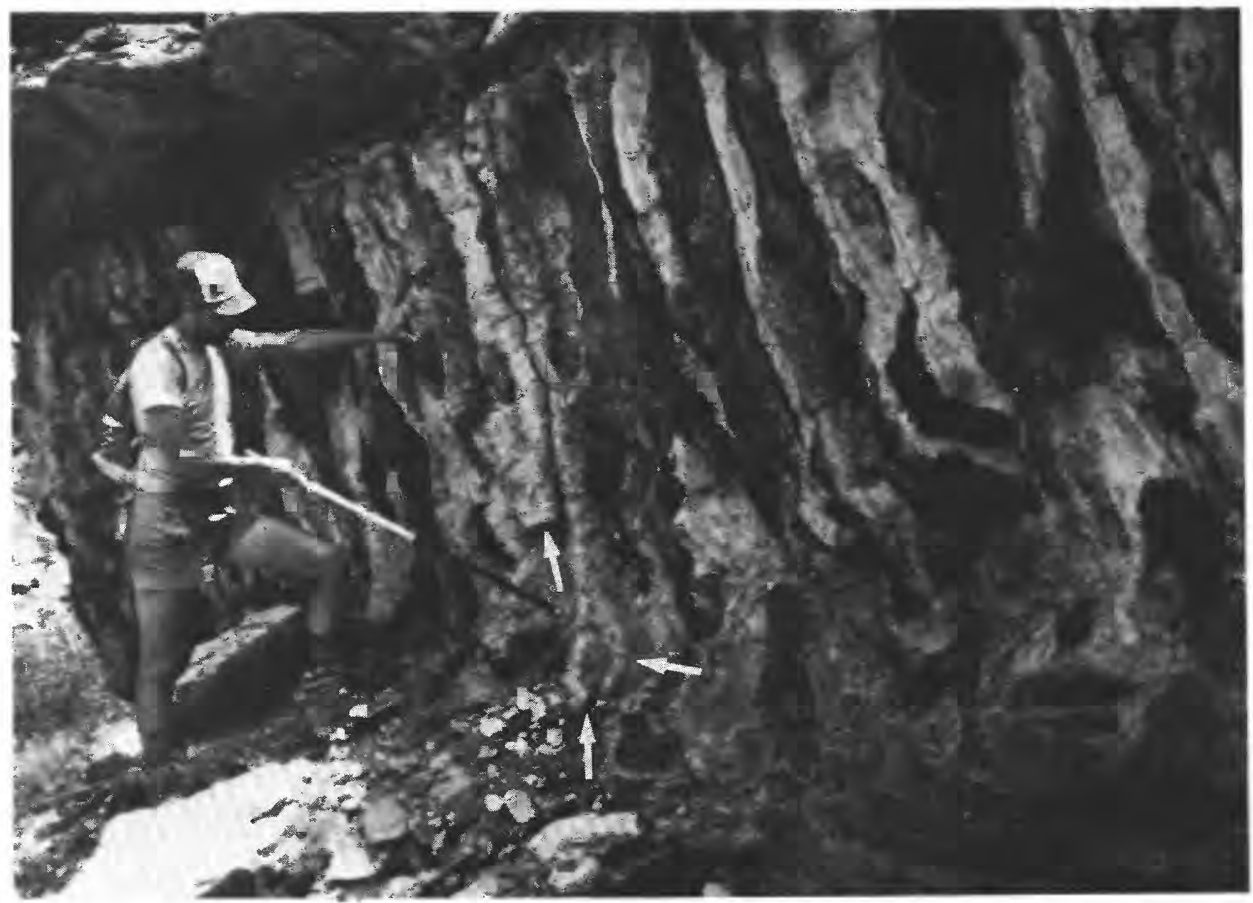

Figure 6. Purple-mottled sandstones of the Temple Mountain Member at the base of the Chinle Formation, Buckhorn Wash in the northern San Rafael Swell. Dark areas are purple and light areas are white. Note the distinctive tubular trace fossils (arrows) within the mottles. 


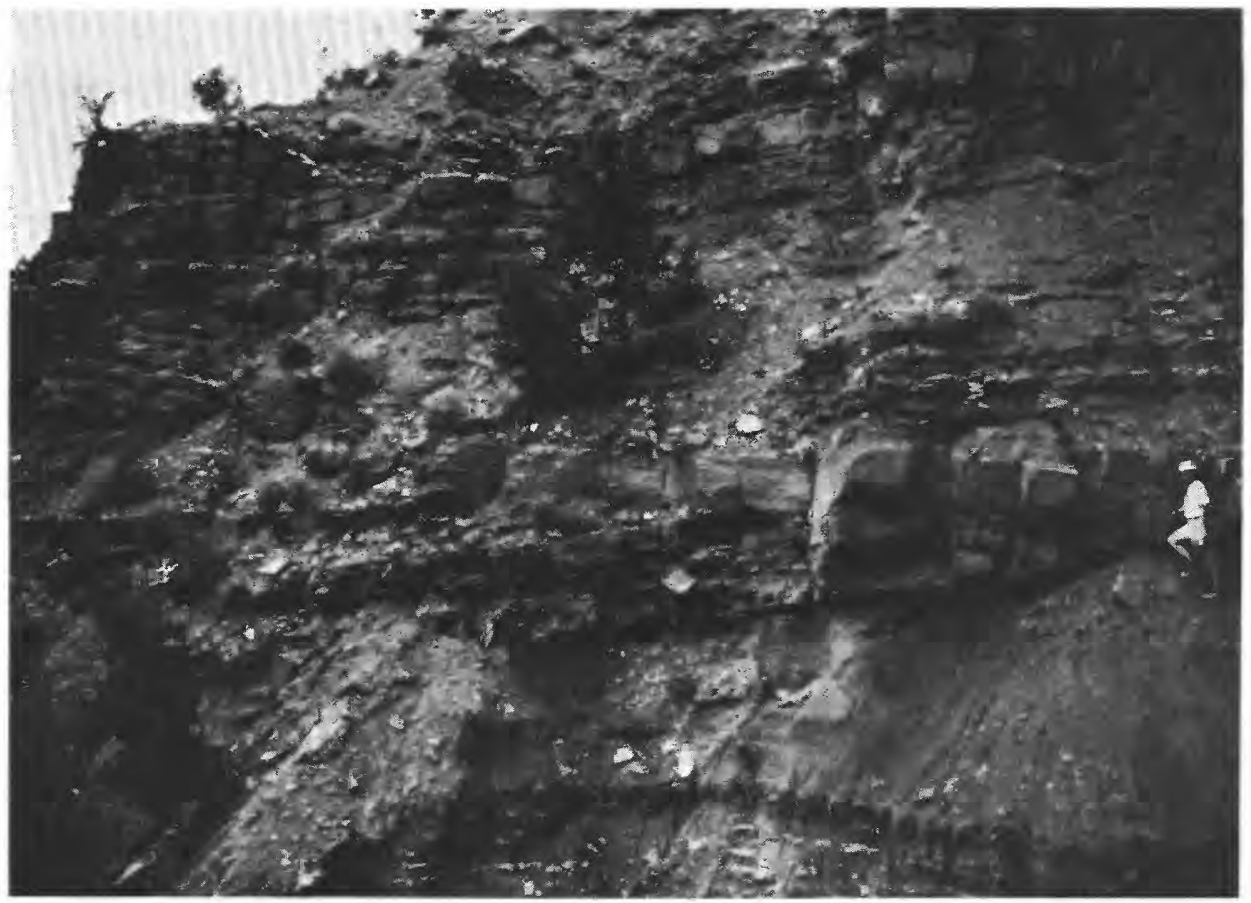

Figure 7. Lower part of the red siltstone member of the Chinle Formation near Derby Junction, Eagle basin, Colorado. Lateral-accretion stratification dipping to the right was deposited as point bars in high-sinuosity fluvial systems. Geologist at right center for scale.

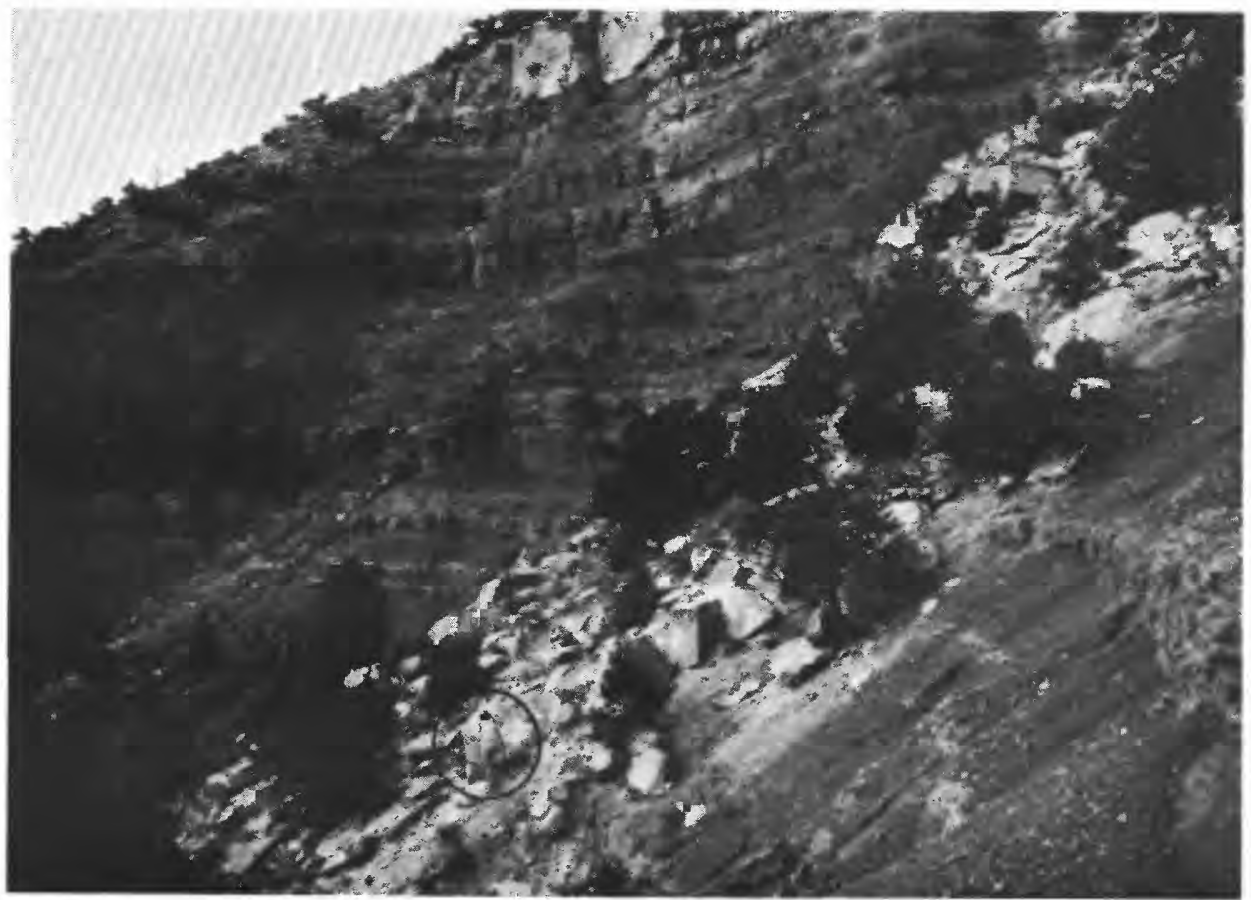

Figure 8. Upper part of the red siltstone member of the Chinle Formation near Derby Junction, Colorado. Horizontally stratified, fine-grained sandstone and siltstone were deposited on fluvial floodplains. At this location, the floodplain deposits display extensive pedogenic modification. Thick white cliff at top is the Entrada Sandstone, which unconformably overlies the Chinle at this location. Geologist (circled) at lower left for scale. 


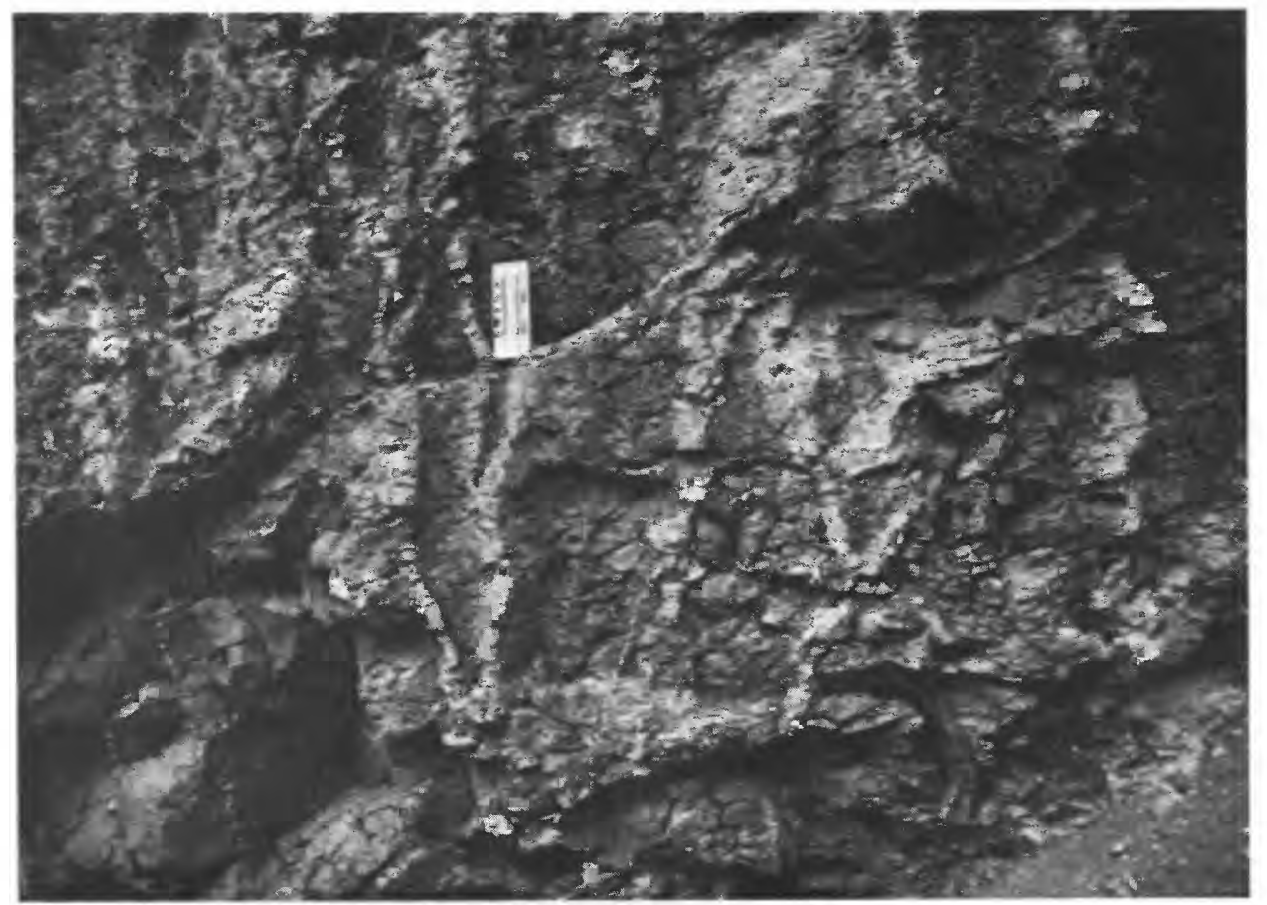

Figure 9. Intersecting sandstone-filled mudcracks in the lower part of the red siltstone member of the Chinle Formation near Derby Junction, Eagle basin, Colorado. Abundant mudcracks are in cut bank of high-sinuosity fluvial strata and indicate repeated wetting and drying of the sediments during episodic flood events. Scale at upper left is marked in centimeters (left) and inches (right).

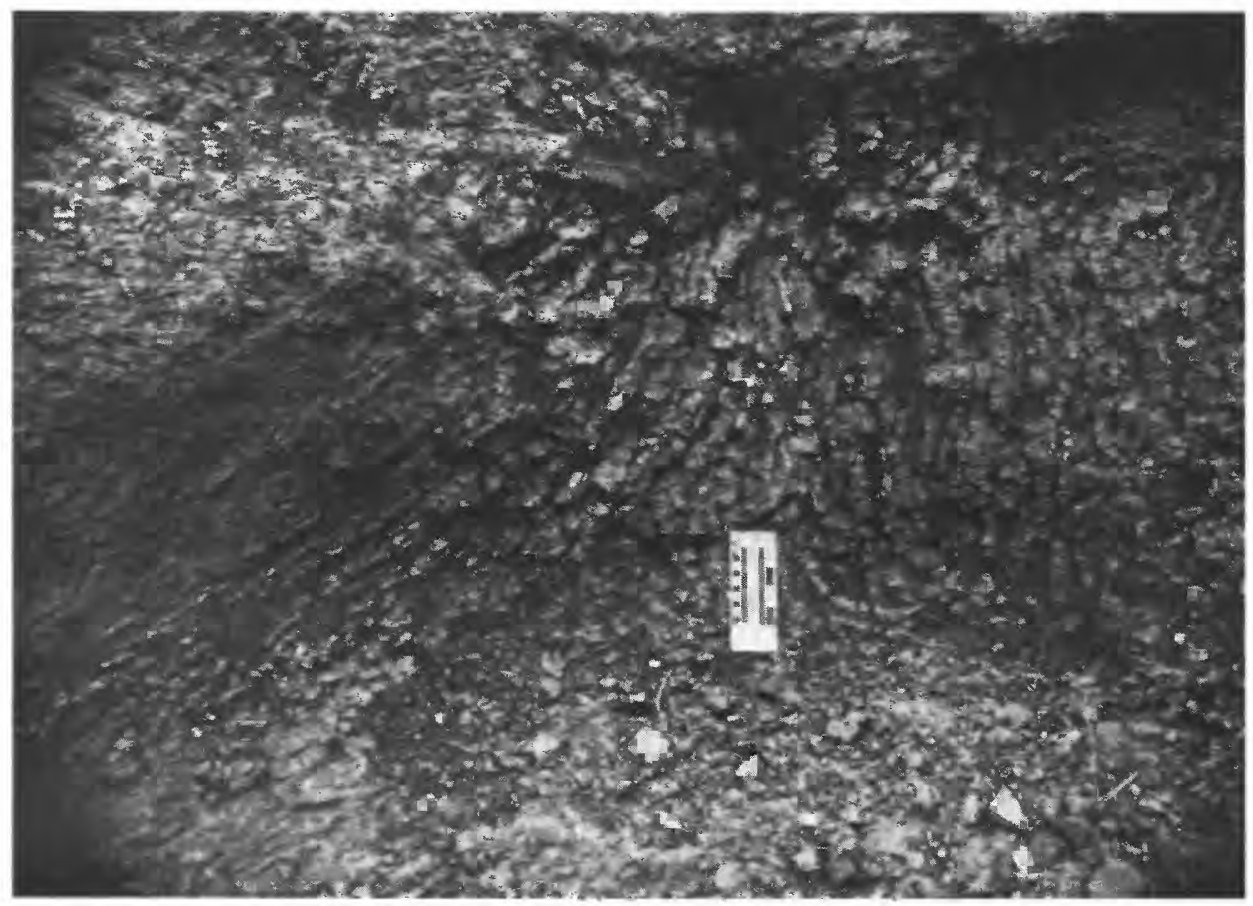

Figure 10. Pseudoanticlines in paleosols of the middle part of the red siltstone member of the Chinle Formation near Derby Junction, Eagle basin, Colorado. Paleosols are formed on floodplain deposits. Pseudoanticlines, also called gilgai microrelief, are formed in surface soil horizons as the result of horizontal compressive stresses caused by expansion of clays and growth of carbonate nodules caused by repeated wetting and drying cycles. Scale at lower right is marked in centimeters (left) and inches (right). 


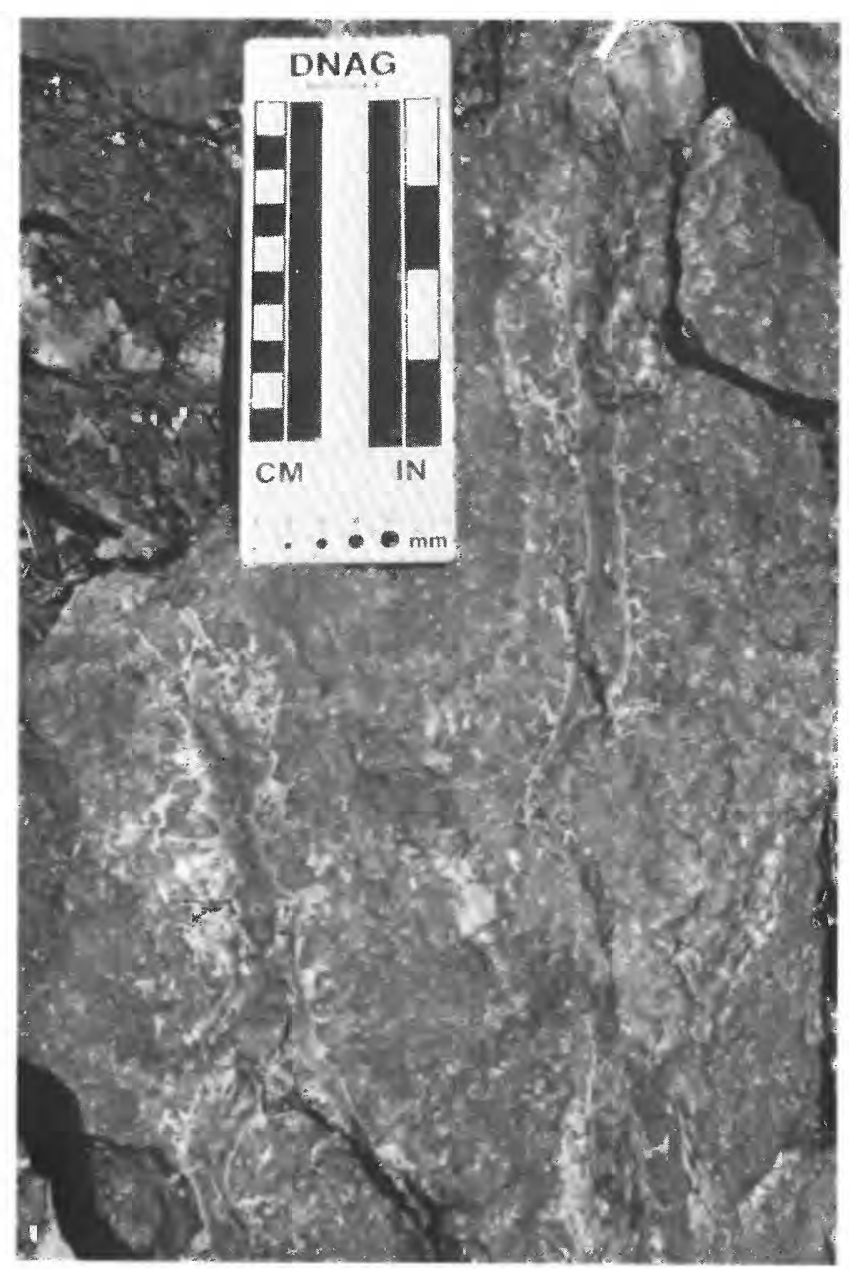

Figure 11. Root alteration haloes, or rhizoliths, in the red siltstone member of the Chinle Formation near East Brush Creek, Eagle basin, Colorado. The rhizoliths exhibit a downward branching and tapering morphology. Scale marked in centimeters (left) and inches (right).

criteria, however, was recently questioned by D'Allessandro and Bromley (1987). These small traces were probably formed as the fodinichnia of sedimentingesting invertebrates and indicate a quiet-water depositional setting and a low sedimentation rate. The burrows are present in the floodplain lithofacies, but extensive bioturbation has destroyed any physical sedimentary structures and interpretations of these strata are difficult. Although present within the floodplain lithofacies, these bioturbated units were probably deposited in small ponds on the floodplains.

Vertebrate remains are conspicuously absent from red strata of the Chinle Formation. The section at Derby Junction did produce two vertebrate fossils from rocks of the floodplain lithofacies. A vertebral centrum of Hesperosuchus (J.M. Parrish, written commun., 1988), a 3-ft-long crocodylomorph, was recovered from the upper part of the Chinle. The similarity between this crocodylomorph and modern crocodiles supports the interpretation of fluvial and floodplain systems in which aquatic habitats were abundant. One additional unidentified vertebrate fossil was observed in a limestone bed that was probably deposited in a small pond within the floodplain facies.

The floodplain strata, paleosols, and rhizoliths are intimately associated with the meandering stream deposits and have a similar distribution in the study area (fig. 4). The floodplain deposits and the associated paleosols and rhizoliths are very abundant in the red siltstone member of the Eagle basin and are rare to absent in the Uinta Mountains, near Dinosaur National Monument, and in the San Rafael Swell. Similar features are present in the Chinle on the western flank of the Uncompahgre uplift near Bedrock (Dubiel, Good, and Parrish, 1989) and in the Dolores Formation (Blodgett, 1984, 1988, 1990). The paleosols and the rhizoliths are restricted to proximal settings of the Chinle depositional system in which subaerial floodplains formed lateral to fluvial systems and for which the sedimentation rate was low enough so as not to inhibit the development of soil horizons.

\section{Lacustrine-Delta and Crevasse-Splay Deposits}

Reddish-brown to brown and gray sandstone and minor conglomerate that form thin, laterally restricted to persistent beds are common within many of the Chinle sections and locally makes up a significant part of the Chinle at other sections. These lithofacies are found in the sandstone and conglomerate member in the eastern part of Dinosaur National Monument and in the Moss Back and Church Rock Members of the San Rafael Swell (fig. 4). The conglomerate is thin bedded and contains siliciclastic and carbonate nodules that are generally less than 1 in. $(2.5 \mathrm{~cm})$ in diameter. The sandstone is thin to medium bedded and is characterized by abundant small- to medium-scale trough crossbedding, very abundant climbing-ripple laminations, abundant horizontal laminations, and minor symmetrical oscillation ripples. Both units exhibit abundant cut-and-fill features and locally superposed, small- to medium-sized lenticular scours (fig. 12).

The units range in size from small lenticular bodies that can be traced over tens of yards to units that make up large parts of the section. Each can be traced laterally into fine-grained strata of either the floodplain or lacustrine lithofacies. Sedimentary structures indicative of channelized flow are present, as are features indicative of rapid sedimentation, standing water, and wave reworking. The lateral facies relationships indicate an environment of deposition lateral to both fluvial systems and lacustrine and floodplain settings. The strata are interpreted to be laterally extensive lacustrine deltas and smaller crevasse-splay deposits. High and others (1969) also interpreted the sandstone and conglomerate unit in eastern Dinosaur National Monument as a lacustrine delta. Many of the strata in the Moss Back and Church Rock Members in the San Rafael Swell previously have been interpreted as fluvial 


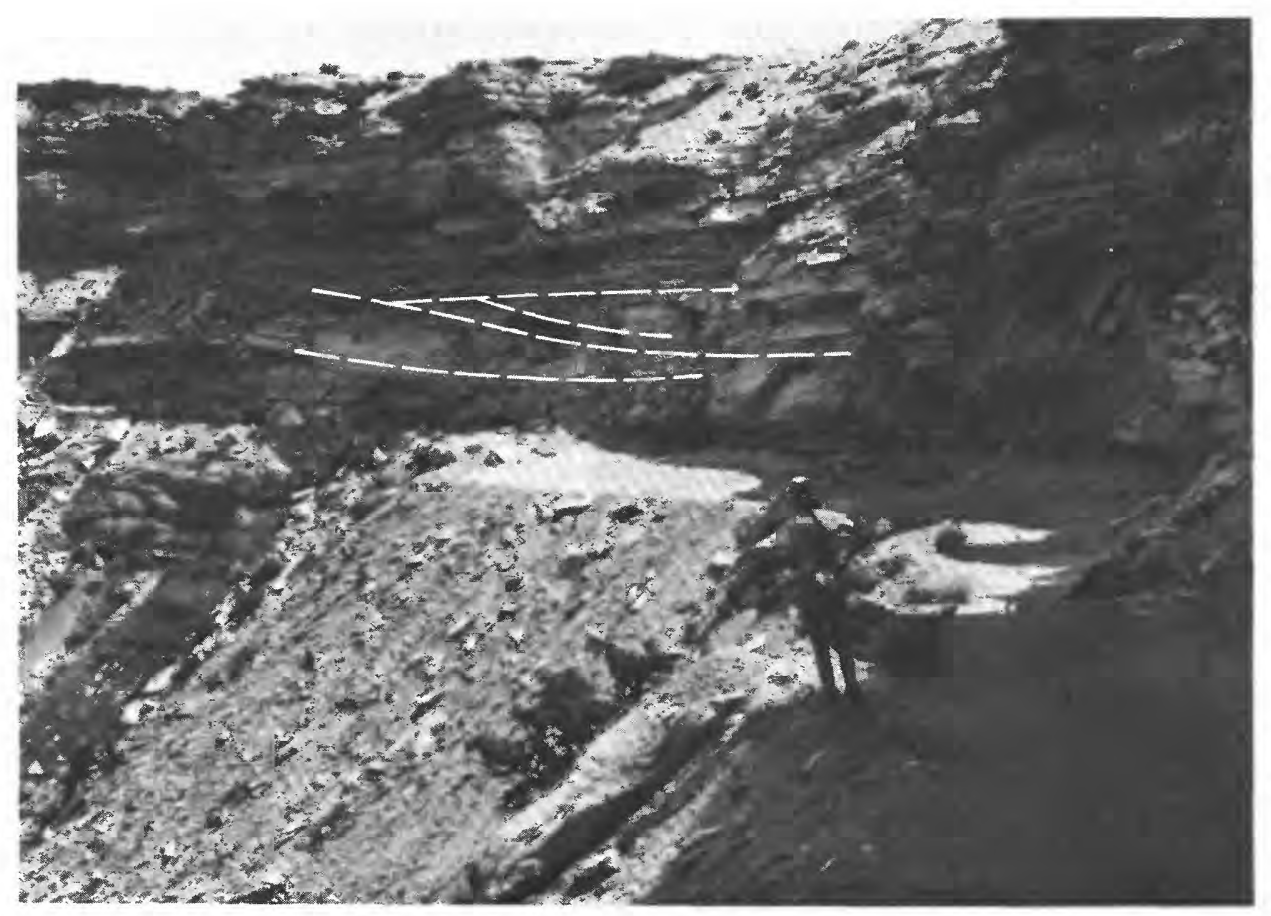

Figure 12. Lacustrine-deltaic strata in the Moss Back Member of the Chinle Formation, Temple Mountain, San Rafael Swell, Utah. The deltaic deposits contain abundant cut-and-fill structures (dashed), small-scale crossbedding, and abundant silicified logs.

deposits (Stewart and others, 1972; Lupe, 1977, 1979). Although many of these units represent deposition by channelized flow, other attributes of the rocks, particularly the fining-upward sequences into abundant climbing and oscillation ripples, interbedded burrowed and bioturbated mudstone, and lateral facies changes into fine-grained rocks, all indicate a lacustrine-deltaic interpretation for the upper part of the sandstone and conglomerate sequence. These coarse-grained units probably represent fluvial deposition at the base and a facies change both upward and distally into proximal and distal deltaic lithofacies.

\section{Lacustrine Deposits}

Many thin-bedded to laminated, horizontally stratified and aerially extensive fine-grained units are exposed in the upper part of the Chinle Formation throughout the study area. These deposits include the red siltstone member, the ocher siltstone member, the upper member, and, in the San Rafael Swell, parts of the Church Rock Member. The units range in color from reddishbrown, to reddish-orange, reddish-purple, yellow, yellowish-brown, and light-brown, to tan. The beds consist of very fine grained sandstone, siltstone, abundant mudstone, and rare gray to pink limestone. The strata exhibit very thin laminations and abundant climbing-ripple crossstratification or symmetrical-ripple laminations (fig. 13).
Sedimentary structures are absent in many of the units, but the strata do contain trace fossils or exhibit a bioturbated fabric.

The fine grain size of the clastic strata, local carbonate beds, tabular and laterally extensive thin beds, abundant bioturbation, and a distinct lack of rhizoliths suggest a lacustrine origin for this lithofacies. The finegrained strata were deposited from suspension in a quietwater environment. Symmetrical oscillation ripples and abundant unidirectional climbing ripples indicate shallowwater, marginal-lacustrine settings and deposition by waves and bottom currents, respectively.

In the Uinta Mountains, a distinctive yellow to yellowish-brown unit in the upper Chinle has been referred to as the ocher unit (High and others, 1969) or the ocher siltstone member (Stewart and other, 1972). The unit is predominantly mudstone and siltstone and contains very thin sandstone beds. It is characterized by the presence of analcime nodules and spherules that are probably the result of volcanic ash fall into the waters of a saline-alkaline lake (Keller, 1952, 1953; High and others, 1969). The analcimerich strata in the Uinta Mountains have been correlated with a similar yellowish-brown, analcime-bearing unit within the Upper Triassic Popo Agie Formation in central Wyoming; in fact, the analcime is the basis for the contention that the Upper Triassic rocks in the eastern Uinta Mountains should be included in the Popo Agie (High and others, 1969). X-ray 

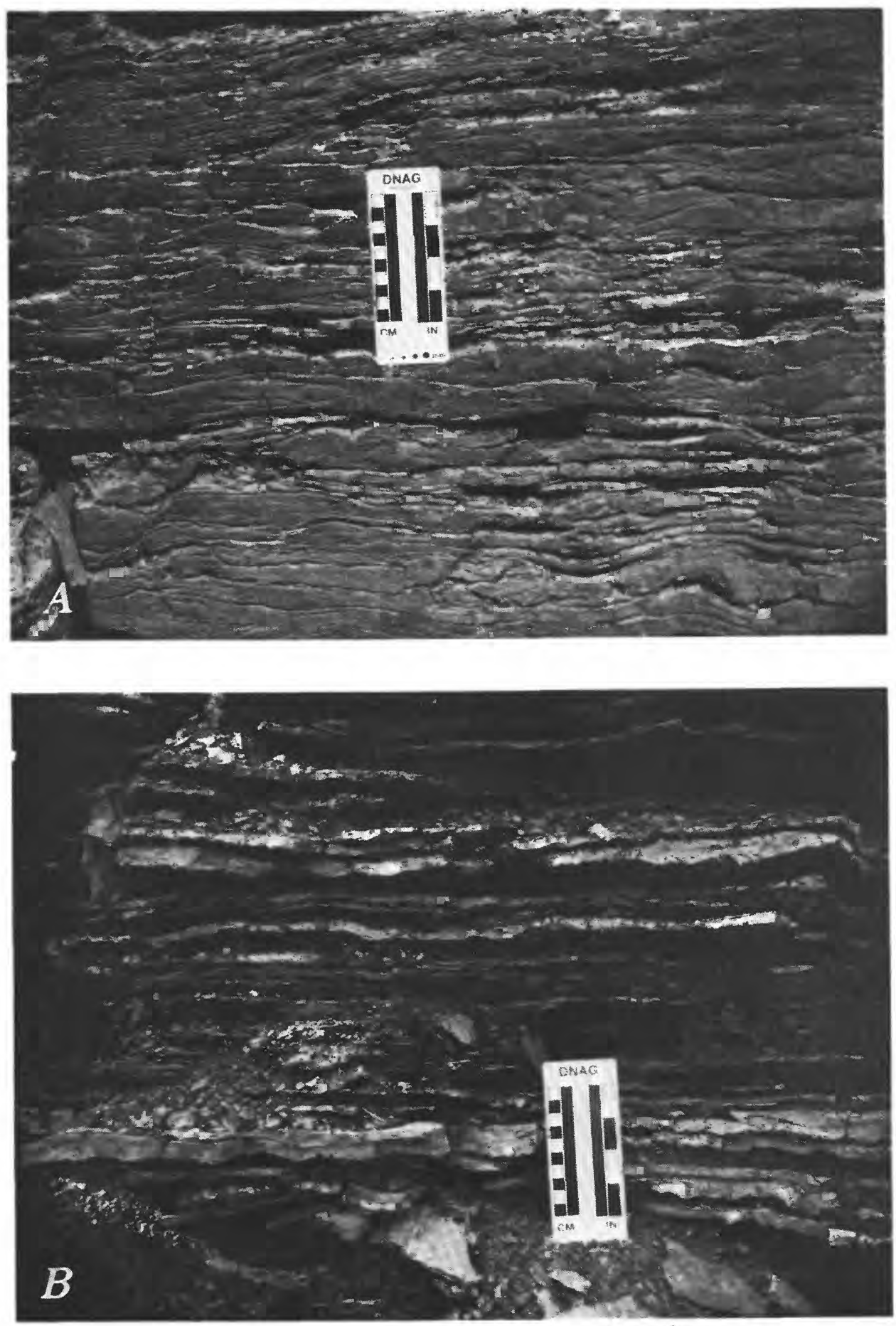

Figure 13. Lacustrine deposits in the Chinle Formation. Scale marked in centimeters (left) and inches (right). $A$, Abundant ripple cross-stratification in the red siltstone member of the Chinle Formation at Skull Creek south of Dinosaur National Monument. B, Interbedded mudstone and fine-grained sandstone containing oscillation ripples and fine, horizontal laminations, near Hanna, Utah, south of the Uinta Mountains.

diffraction and petrographic thin-section analyses of several samples collected during the present study from the yellowish-brown unit in the Uinta Mountains confirm the presence of analcime in nodules and spherules, and it is likely that these strata reflect deposition of clastic sediment and air-fall volcanic ash into a saline-alkaline lake as suggested by Keller (1952). The fact that this unit interfingers with other lacustrine units of the Chinle in the region 
that lack analcime indicates that the saline-alkaline lacustrine conditions were not persistent throughout the region nor did they exist for the duration of Chinle deposition. The analcime-bearing unit extends from the Popo Agie Formation in Wyoming to outcrops of the Chinle Formation in the Uinta Mountains, but it is absent in equivalent outcrops of the Chinle farther to the south in Utah. The lacustrine system proposed to have existed in southern Wyoming by High and others (1969) probably expanded south at times into the area of the Uinta Mountains and deposited the ocher unit in both regions.

Freshwater lacustrine systems existed during deposition of the Monitor Butte and Owl Rock Members of the Chinle Formation in the Four Corners region (Dubiel, 1987a, b, 1989a). The presence of a saline-alkaline lake farther north in Wyoming during deposition of the Popo Agie Formation suggests that more arid climatic conditions existed in this northern area. This relationship is consistent with paleogeographic and paleoclimatic reconstructions for the depositional basin and is discussed in a subsequent section.

\section{Eolian Deposits}

A distinct lithofacies consisting of eolian deposits is restricted to the upper part of the Chinle Formation in the central part of the Eagle basin (fig. $4 A$ ). The eolian deposits consist of reddish-orange to light-orange-brown, thin- to thick-bedded, horizontally laminated to low-angle crossstratified, very fine to fine grained sandstone and lightred-brown siltstone (fig. 14). The thin, parallel and wavy laminations are locally highlighted by very thin clay drapes that are mudcracked on a very small scale and contain small, meniscate-backfilled trace fossils. The eolian lithofacies does not contain the abundant rhizoliths characteristic of the floodplain deposits but is instead characterized by abundant, small trace fossils and a bioturbated texture.

The horizontal laminations in fine to very fine grained sandstone, the thin clay drapes, and the thick, laterally extensive tabular bedding suggest an origin as eolian sand sheets and minor eolian dunes (Kocurek and Nielson, 1986). Similar eolian sand sheets have been described from the Dolores Formation in southwestern Colorado (Blodgett, 1984, 1988, 1990). Eolian and sand-sheet facies are present only in the three thickest sections of the Chinle measured for this study. This possibly implies that a part of this lithofacies and an unknown part of the upper Chinle was removed by erosion prior to deposition of the overlying strata elsewhere. The stratigraphically upward change from subaerial and subaqueous depositional facies in the lower Chinle to predominantly eolian deposits at the end of Chinle time indicates a significant drying of the overall climate at the close of the Late Triassic.

A second possible correlation exists for the lightorange eolian beds at the top of the section. These eolian beds beneath the Entrada Sandstone in the Eagle basin may correlate to the Wingate Sandstone farther to the west and thus may represent erosional remnants of the Wingate preserved beneath the Triassic-Jurassic unconformity in this small area of the Eagle basin. An unconformity was not recognized in the sections between the floodplain facies below and the eolian facies above; however, such a contact might be difficult to recognize in a flatbedded sequence composed of similar eolian facies.

\section{DEPOSITIONAL SYSTEMS AND PALEOGEOGRAPHY}

The reddish-brown conglomerate, sandstone, siltstone, and mudstone of the Chinle Formation in western Colorado within the Eagle basin were deposited in a succession of fluvial channel, floodplain, lacustrine-deltaic, lacustrine, and eolian environments. Coarse-grained sediment was deposited within paleovalleys eroded into underlying rocks by fluvial systems that generally flowed northwest. Deposits at the base of the Chinle are coarse grained, they exhibit more numerous cut-and-fill features, and they lack lateral-accretion bedding compared to overlying deposits. The basal conglomerates represent fluvial deposition in low-sinuosity fluvial and valley-fill systems. As the paleovalleys filled with sediment, gradients on the streams were lowered, and Chinle sedimentation was mainly by fluvial deposition within moderate- to highsinuosity channel systems. Overbank flooding by the streams deposited fine-grained floodplain strata. Floodplain units are characterized by petrocalcic and vertic paleosols that contain rhizoliths and abundant trace fossils. In places, small ponds formed on the floodplains.

The direction of transport of clastic material for the Chinle depositional systems in northwestern Colorado was north and northwest from the ancestral Uncompahgre uplift, which formed the bounding highland on the southwestern part of the basin, and south and west from the ancestral Front Range uplift, which was the source area on the eastern margin of the basin (fig. 15). Paleostream directions determined from plots of maximum pebble size and trend of crossbed axes in fluvial rocks indicate that paleoflow was to the northwest in the Eagle basin (Stewart and others, 1972; Shropshire, 1974).

Stratigraphic panels of measured sections (fig. $4 A$ ) depict a thinning of the Chinle Formation along the margins of the Eagle basin near the flanks of the uplifts. The thinning probably results both from erosion of the upper part of the Chinle prior to deposition of the overlying rocks and from increased subsidence and preservation along the northwesttrending axis of the Eagle basin. Increased subsidence in the central Eagle basin near East Brush Creek is supported by the fact that the thickest preserved section of the Chinle is present at this location. The thickest section of the Chinle in this area is coincident with a thicker section of the 

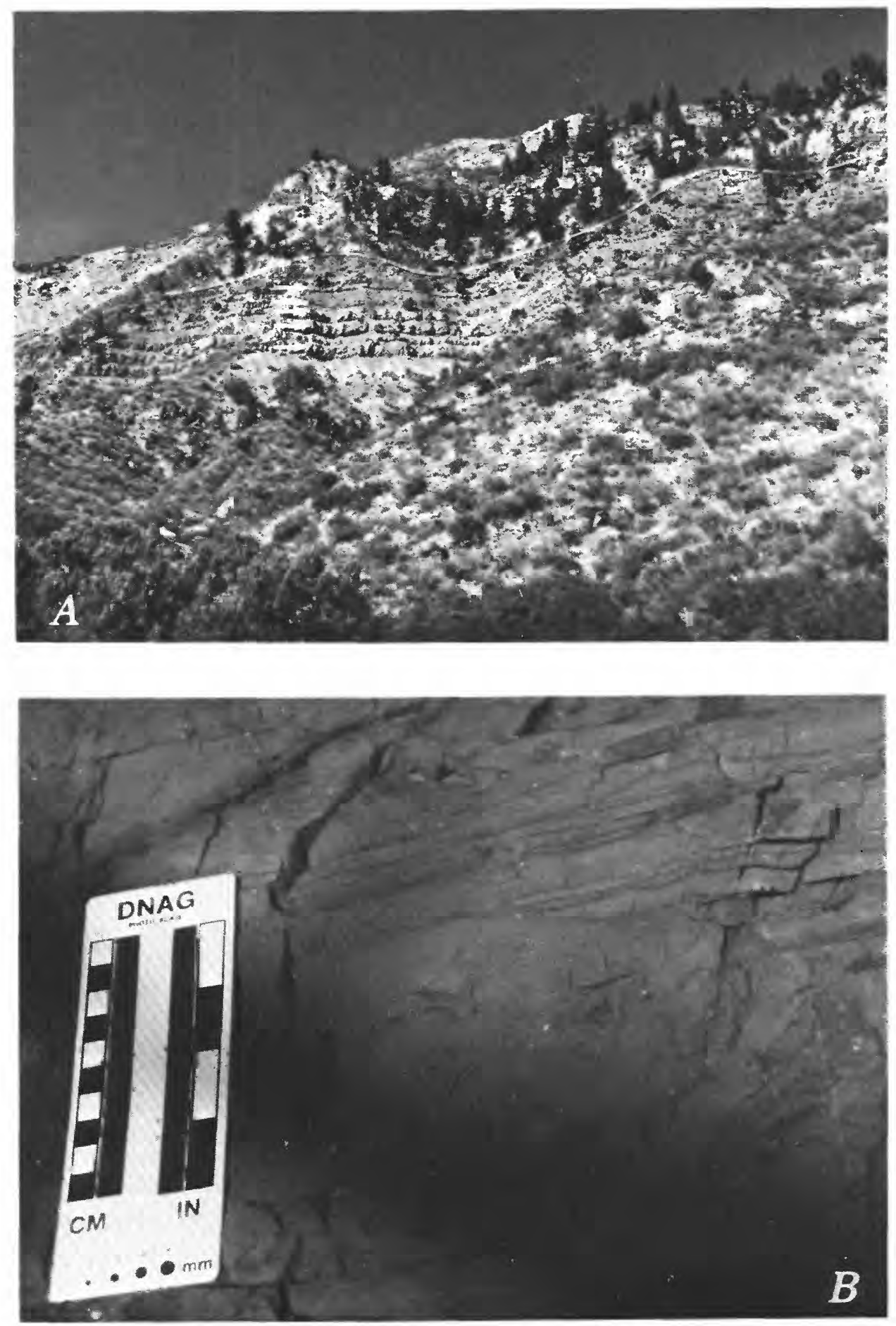

Figure 14. Eolian deposits at the top of the Chinle Formation, East Brush Creek, Eagle basin, Colorado. A, Eolian sand sheet strata $(\mathrm{kc})$ at the top of the Chinle Formation (arrows) unconformably overlain by the Lower Jurassic Entrada Sandstone (Je). About $200 \mathrm{ft}(60 \mathrm{~m})$ of eolian strata exposed. B, Eolian sand sheet showing horizontal laminations and thin clay drapes.

Pennsylvanian and Permian State Bridge Formation (S.Y. Johnson, oral commun., 1988). The greater subsidence in this area inferred from the increased thickness of the Chinle and the State Bridge may reflect increased tectonic subsidence, or it may be related to subsidence as a result of movement of salt in the underlying Pennsylvanian Eagle Valley Evaporite (R.J. Hite, U.S. Geological Survey, oral commun., 1989). 


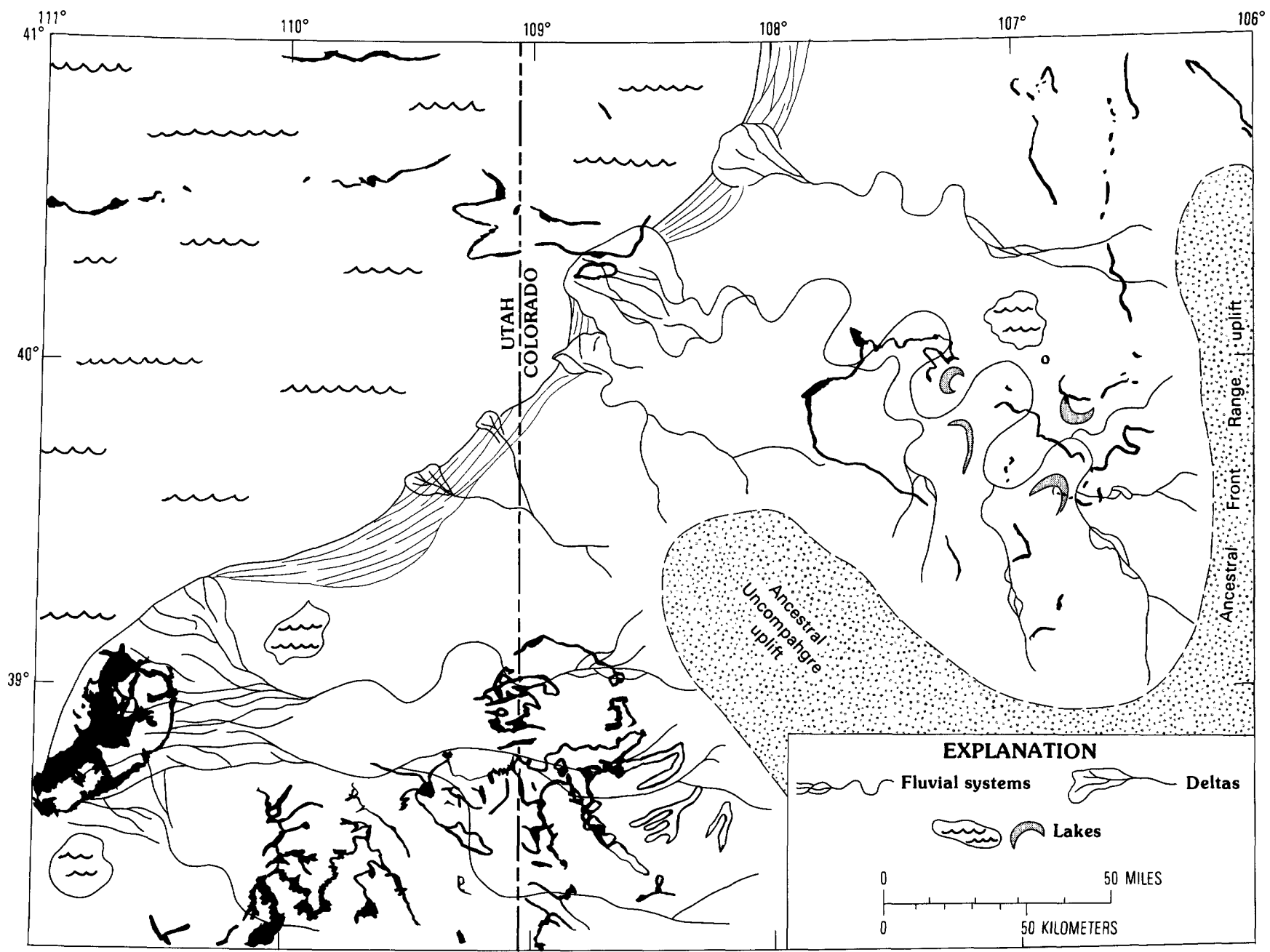

Figure 15. Schematic reconstruction of Chinle depositional systems in the Uinta, Piceance, and Eagle basins. Diagram shows paleogeography and location and trend of major fluvial, deltaic and lacustrine systems. Outcrops of Chinle Formation shown in black. Compare to figure 2 for locations of measured sections.

Stratigraphic panels of the Chinle Formation across the Uinta Mountains into northeastern Utah and northwestern Colorado near Dinosaur National Monument (fig. $4 B$ ) depict the sequence of depositional environments in this region. Conglomerates and sandstones at the base of the Chinle represent the initial development of fluvial systems. These fluvial strata contain mostly carbonate intraclasts and very few siliciclastic pebbles, a composition indicating an intrabasinal source for the pebbles. It is likely that the ancestral Rocky Mountains were reduced in elevation or even covered by Chinle deposits at this time. Fluvial systems were succeeded by a large lacustrine system. Aspects of the lacustrine facies, such as the presence of analcime, indicate not only that the lake was at times saline and alkaline, but also that it was, at least in part, contiguous with a large lake system interpreted to have existed in the Upper Triassic Popo Agie Formation farther to the north in Wyoming. The presence of limestone in the sections in the eastern part of Dinosaur National Monument attests to the lack of clastic and volcanic detritus in some lacustrine settings. Lacustrine deltas, which provided clastic material to the lake, existed in the eastern Uinta Mountains. The deltas were fed in part by fluvial systems that flowed northwest out of the Eagle basin and northwest off of the northwestern flank of the ancestral Uncompahgre uplift.

Preliminary studies in the San Rafael Swell, Colorado National Monument, (fig. 4B) and near Bedrock, Colorado (Dubiel, Good, and Parrish, 1989), provide insight about the relationship between Chinle environments there to those in the Uinta, Piceance, and Eagle basins. The Moss Back and Church Rock Members in the sections measured in the San Rafael Swell represent fluvial and deltaic deposition that flowed northwest into a large lake. Lacustrine strata at the top of the Chinle in the San Rafael Swell probably correlate with similar strata at the top of the Chinle in the Uinta Mountains, although the distances between the outcrops are very large. The lacustrine deposits may also be correlative, but, as suggested by McCormick and Picard (1969), additional unrecognized facies changes may be present beneath the Uinta basin. 


\section{PALEOCLIMATE}

Several aspects of the sedimentology of the Chinle Formation can be used to infer the paleoclimate during Chinle deposition. Paleomagnetic reconstructions place this part of the Colorado Plateau at about $5^{\circ}-15^{\circ} \mathrm{N}$. paleolatitude, clearly within the tropics, during the Late Triassic (Van der Voo and others, 1976; Bazard and Butler, in press). Temperatures probably were warm to hot the entire year. The fluvial, floodplain, and lacustrine deposits indicate that water was abundant in the Chinle depositional system, at least until eolian deposition in the final stages of Chinle time. In a tropical setting, the accumulation of pedogenic calcic horizons, in particular the presence of single, indurated carbonate nodules in clay-rich soils, is characteristic of seasonal precipitation. Additionally, the presence of vertic paleosol features such as abundant desiccation cracks and pseudoanticlines representing gilgai micro-relief indicates that moisture input to the floodplains, either by flooding of the fluvial systems or by precipitation, was seasonal (Mohr and others, 1972; Young, 1976). Thus the region of Chinle deposition in the Uinta, Piceance, and Eagle basins probably had a tropical monsoonal climate. A tropical monsoonal climate has been suggested for that part of the Chinle depositional basin around the Four Corners region (Dubiel, 1987a, c, 1989a; Parrish and others, 1989; Dubiel and others, 1991) and is thought to result from the unique configuration of the supercontinent Pangea during the Late Triassic and the location of the Colorado Plateau near the western edge of that continent (Dubiel, 1989b; Parrish and others, 1989; Dubiel and others, 1991). The advent of eolian deposition in the final stages of Chinle deposition both in this region and in the Four Corners area (Dubiel, 1989a, b) supports the concept that climate became significantly drier at the close of the Late Triassic. The change to a drier climate was probably the result of the northward migration of Pangea, moving the Colorado Plateau northward out of latitudes affected by monsoonal circulation and into the drier mid-latitudes (Parrish and others, 1989; Dubiel and others, 1991). In contrast to the lacustrine systems of the Chinle of the Four Corners region, the development of a saline-alkaline lake within the Popo Agie Formation is probably due to the position of the Popo Agie depositional basin farther north in Pangea and in drier latitudes not under the direct influence of the monsoonal circulation.

\section{CONCLUSIONS}

The Chinle Formation represents a sequence of continental lithofacies deposited in a complex fluvialdeltaic-lacustrine-eolian system. Individual depositional environments reflect the interaction of tectonic, paleogeographic, and climatic controls. Analysis of depositional systems in widely separated areas can be used to reconstruct the paleogeography of the Chinle basin throughout the Colorado Plateau and beyond its present margins.

Lithofacies analysis reveals several distinct continental depositional environments within the Chinle Formation of the Uinta, Piceance, and Eagle basins. In settings adjacent to the ancestral Uncompahgre and Front Range uplifts, the Chinle is characterized by basal valley-fill gravels overlain by meandering fluvial and associated floodplain sequences replete with paleosols and small ponds. These facies are present on all flanks of the ancestral Uncompahgre uplift. The fluvial facies grade westward and northwestward toward the Uinta and Piceance basins into lacustrine-deltaic and lacustrine deposits. The close of Chinle deposition in the Eagle basin, where the greater thickness of Chinle Formation is preserved, is dominated by eolian sand-sheet strata. Tropical monsoonal circulation affecting the western coast of Pangea provided abundant but seasonal moisture to the Chinle depositional basin until the end of the Late Triassic. The close of Chinle deposition is marked by eolian strata that indicate a change to significantly drier conditions as Pangea migrated northward in the latest Triassic and earliest Jurassic and moved the Colorado Plateau northward into drier latitudes.

\section{REFERENCES CITED}

Allen, J.R.L., 1963, The classification of cross-stratified units, with notes on their origin: Sedimentology, v. 2, p. 93-114. 1965a, A review of the origin and characteristics of Recent alluvial sediments: Sedimentology, v. 5, p. 89-191. $1965 \mathrm{~b}$, The sedimentology and paleogeography of the Old Red Sandstone of Anglesey, North Wales, Yorkshire: Geological Society Proceedings, v. 35, p. 139-185.

1974, Studies in fluviatile sedimentation: implications of pedogenic carbonate units in the Lower Old Red Sandstone, Anglo-Welsh outcrop: Geology Journal, v. 9, p. 181-208.

Bazard, D.R., and Butler, R.F., in press, Paleomagnetism of the Chinle and Kayenta Formations, New Mexico and Arizona: Journal of Geophysical Research.

Blakey, R.C., and Gubitosa, Richard, 1983, Late Triassic paleogeography and depositional history of the Chinle Formation, southeastern Utah and northeastern Arizona, in Reynolds, M.W., and Dolly, E.D., eds., Mesozoic paleogeography of the west-central United States: Rocky Mountain Section, Society of Economic Paleontologists and Mineralogists, p. 57-76.

Blodgett, R.H., 1984, Nonmarine depositional systems and paleosol development in the Upper Triassic Dolores Formation, southwestern Colorado, in Brew, D.C., ed., Field trip guidebook: 37th Annual Meeting, Rocky Mountain Section, Geological Society of America, Durango, p. 46-61.

1988, Calcareous paleosols in the Upper Triassic Dolores Formation southwest Colorado, in Reinhardt, J., and Sigleo, W.R., eds., Paleosols and weathering through geologic time: Geological Society of America Special Paper 216, p. 103-122. 
1990, Nonmarine depositional environments and paleosol development, Upper Triassic Dolores Formation, southwestern Colorado: University of Texas at Austin, Ph.D. thesis, 646 p.

Bown, T.M., and Kraus, M.J., 1987, Integration of channel and floodplain suites in aggrading alluvial systems: Developmental sequence and lateral relations of lower Eocene alluvial paleosols, Willwood Formation, Bighorn Basin, Wyoming: Journal of Sedimentary Petrology, v. 57, p. 587-601.

Busbey-Spera, Cathy, 1988, Speculative tectonic model for the early Mesozoic arc of the southwest Cordilleran United States: Geology, v. 16, p. 1121-1125.

D'Allessandro, A.D., and Bromley, R.G., 1987, Meniscate trace fossils and the Muensteria-Taenidium problem: Paleontology, v. 30, p. 743-763.

Dickinson, W.R., 1981, Plate tectonic evolution of the southern Cordillera, in Dickinson, W.R., and Payne, W.D., eds., Relations of tectonics to ore deposits in the southern Cordillera: Arizona Geological Society Digest, v. 14, p. 113-135.

Dubiel, R.F., 1983, Sedimentology of the lower part of the Upper Triassic Chinle Formation and its relationship to uranium deposits, White Canyon area, southeastern Utah: U.S. Geological Survey Open-File Report 83-459, 48 p.

1987a, Sedimentology of the Upper Triassic Chinle Formation, southeastern Utah: Boulder, University of Colorado, Ph.D. thesis, $132 \mathrm{p}$.

1987b, Sedimentology and new fossil occurrences of the Upper Triassic Chinle Formation, southeastern Utah, in Campbell, J.C., ed., The geology of Cataract Canyon and vicinity: Four Corners Geological Society, 1987 Field Conference Guidebook, p. 99-107.

1987c, Sedimentology of the Upper Triassic Chinle Formation, southeastern Utah-Paleoclimatic implications, in Morales, M., and Elliott, D.K., eds., Triassic continental deposits of the American Southwest: Journal of the Arizona-Nevada Academy of Science, v. 22, p. 35-45.

1988, Rhizoliths and rhizofacies in floodplain paleosols, Upper Triassic Chinle Formation, west-central Colorado: Geological Society of America, Abstracts with Programs, v. 20 , p. A264.

1989a, Depositional and climatic setting of the Upper Triassic Chinle Formation, Colorado Plateau, in Lucas, S.G., and Hunt, A.P., eds., Dawn of the age of dinosaurs in the American Southwest: New Mexico Museum of Natural History, Spring Field Conference Guidebook, p. 171-187.

1989b, Sedimentology and revised nomenclature for the upper part of the Upper Triassic Chinle Formation and the Lower Jurassic Wingate Sandstone, northwestern New Mexico and northeastern Arizona, in Anderson, O.J., Lucas, S.G., Love, D.W., and Cather, S.M., eds., Southeastern Colorado Plateau: New Mexico Geological Society, 40th Field Conference Guidebook, p. 213-223.

Dubiel, R.F., Blodgett, R.H., and Bown, T.M., 1987, Lungfish burrows in the Upper Triassic Chinle and Dolores Formations, Colorado Plateau: Journal of Sedimentary Petrology, v. 57, p. 512-521.
1988, Lungfish burrows in the Upper Triassic Chinle and Dolores Formations, Colorado Plateau-Reply: Journal of Sedimentary Petrology, v. 58, p. 367-369.

1989, Lungfish burrows in the Upper Triassic Chinle and Dolores Formations, Colorado Plateau-Reply: Journal of Sedimentary Petrology, v. 59, p. 876-878.

Dubiel, R.F., Good, S.C., and Parrish, J.M., 1989, Sedimentology and paleontology of the Upper Triassic Chinle Formation, Bedrock, Colorado: The Mountain Geologist, v. 26, p. 113-126.

Dubiel, R.F., Parrish, J.T., Parrish, J.M., and Good, S.C., 1991, The Pangaean megamonsoon-Evidence from the Upper Triassic Chinle Formation, Colorado Plateau: Palaois, v. 6, no. 4, 24 p.

Dubiel, R.F., and Skipp, Gary, 1989, Stratigraphic and sedimentologic studies of the Upper Triassic Chinle Formation, western Colorado: U.S. Geological Survey Open-File Report 89-2, 26 p.

Elliott, D.K., 1983, New material of Chinlea sorenseni from the Chinle Formation, Dolores River, Colorado: Symposium on Southwestern Geology and Paleontology, Flagstaff, Museum of Northern Arizona, p. 4.

1987, A new specimen of Chinlea sorenseni from the Chinle Formation, Dolores River, Colorado, in Morales, M., and Elliott, D.K., eds., Triassic continental deposits of the American Southwest: Journal of the Arizona-Nevada Academy of Science, v. 22, p. 47-52.

Freeman, V.L., 1971, Stratigraphy of the State Bridge Formation in the Woody Creek Quadrangle, Pitkin and Eagle Counties, Colorado: U.S. Geological Survey Bulletin 1324-F, 17 p.

Freeman, V.L., and Bryant, Bruce, 1977, Red bed formations in the Aspen area, Colorado, in Veal, H.K., ed., Exploration frontiers of the central and southern Rocky Mountains: Rocky Mountain Association of Geologists, p. 181-189.

Gile, L.H., Peterson, F.F., and Grossman, R.S., 1966, Morphological and genetic sequences of carbonate accumulation in desert soils: Soil Science, v. 101, p. 347-360.

Harms, J.C., Southard, J.B., Spearing, D.R., and Walker, R.G., 1975, Depositional environments as interpreted from primary sedimentary structures and stratification sequences: Society of Economic Paleontologists and Mineralogists Short Course Notes 2, $161 \mathrm{p}$.

Hasiotis, S.T., and Dubiel, R.F., in press, A morphologic comparison of large-diameter burros from the Upper Triassic Chinle Formation of western Colorado and southeastern Utah: Ichnos, 24 p.

Hasiotis, S.T., and Mitchell, C.E., 1989, Lungfish burrows in the Upper Triassic Chinle and Dolores Formations, Colorado Plateau-Discussion: New evidence suggests origin by a burrowing decapod crustacean: Journal of Sedimentary Petrology, v. 58, p. 871-875.

High, L.R., Jr., Hepp, D.M., Clark, Thomas, and Picard, M.D., 1969, Stratigraphy of Popo Agie Formation (Late Triassic), Uinta Mountain area, Utah and Colorado, in Lindsay, J.B., ed., Geologic guidebook of the Uinta Mountains-Utah's Maverick Range: Intermountain Association of Geologists, 16th Annual Field Conference Guidebook, p. 182-192. 
High, L.R., Jr., and Picard, M.D., 1967, Stratigraphic relations of Upper Triassic units, northeastern Utah and Wyoming: Compass, v. 44 , p. $88-98$.

1969, Stratigraphic relations within upper Chugwater Group (Triassic), Wyoming: American Association of Petroleum Geologists Bulletin, v. 53, p. 1091-1104.

Jackson, R.G., 1976, Depositional model of point bars in the lower Wabash River: Journal of Sedimentary Petrology, v. 46, p. 579-594.

Johnson, S.Y., 1987, Stratigraphic and sedimentologic studies of Late Paleozoic strata in the Eagle basin and the Aspen sub-basin, northwest Colorado: U.S. Geological Survey Open-File Report 87-286, 82 p.

Johnson, S.Y., Schenk, C.J., Anders, D.L., and Tuttle, M.L., 1990, Sedimentology and petroleum occurrence in the Schoolhouse Member of the Maroon Formation (Lower Permian), northwestern Colorado: American Association of Petroleum Geologists, v. 75, p. 135-150.

Keller, W.D., 1952, Analcime in the Popo Agie Member of the Chugwater Formation: Journal of Sedimentary Petrology, v. 22 , p. $70-82$.

1953, Analcime in the Chinle Formation of Utah correlative with Popo Agie of Wyoming: Journal of Sedimentary Petrology, v. 23, p. 10-12.

Kinney, D.M., 1955, Geology of the Uinta River-Brush Creek area, Duschesne and Uintah Counties, Utah: U.S. Geological Survey Bulletin 1007, 185 p.

Klappa, C.F., 1980, Rhizoliths in terrestrial carbonates: Classification, recognition, genesis and significance: Sedimentology, v. 27, p. 613-629.

Kluth, C.F., and Coney, P.J., 1981, Plate tectonics of the Ancestral Rocky Mountains: Geology, v. 9, p. 10-15.

Kocureck, G., and Nielson, J., 1986, Conditions favorable for the genesis of warm-climate aeolian sand sheets: Sedimentology, v. 33, p. 795-816.

Lucas, S.G., and Hayden, S.H., 1989, Triassic stratigraphy of west-central New Mexico, in Anderson, O.J., Lucas, S.G., Love, D.W., and Cather, S.M., eds., Southeastern Colorado Plateau: New Mexico Geological Society, 40th Field Conference Guidebook, p. 191-211.

Lupe, Robert, 1977, Depositional environments as a guide to uranium mineralization in the Chinle Formation, San Rafael Swell, Utah: U.S. Geological Survey Journal of Research, v. 5, p. 365-372.

1979, Stratigraphic sections of the Upper Triassic Chinle Formation, San Rafael Swell to the Moab area, Utah: U.S. Geological Survey Oil and Gas Investigations Chart OC-89.

MacLachlan, M.E., 1957, Triassic stratigraphy in parts of Utah and Colorado: Intermountain Association of Petroleum Geologists, 8th Annual Field Conference Guidebook, p. 83-91.

Mallory, W.W., 1972, Regional synthesis of the Pennsylvanian system, in Mallory, W.W., ed., Geologic atlas of the Rocky Mountains region: Rocky Mountain Association of Geologists, p. 111-127.

McCormick, C.D., and Picard, M.D., 1969, Petrology of Gartra Formation (Triassic), Uinta Mountain area, Utah and Colorado: Journal of Sedimentary Petrology, v. 39, p. 1484-1508.
Miall, A.D., 1984, Principles of sedimentary basin analysis: New York, Springer-Verlag, 490 p.

Mohr, E.C.J., Van Baren, F.A., and Van Schuylenborgh, 1972, Tropical soils: The Hague, Netherlands, Mouton-Ichtiar Baru-Van Hoeve, 480 p.

Moody-Stuart, M., 1966, High- and low-sinuosity stream deposits, with examples from the Devonian of Spitzbergen: Journal of Sedimentary Petrology, v. 36, p. 1102-1117.

Parrish, J.M., Dubiel, R.F., and Good, S.C., in press, New vertebrate and invertebrate fossils in lacustrine and marsh facies, Upper Triassic Chinle Formation, Utah and Colorado: Palaeogeography, Paleoclimatology, and Paleoecology, $27 \mathrm{p}$.

Parrish, J.M., Dubiel, R.F., and Parrish, J.T., 1989, Triassic monsoonal paleoclimate in Pangaea-Evidence from the Chinle Formation southwestern United States: 28th International Geologic Congress, Washington, D.C., Abstracts Volume, v. 2, p. 755-576.

Peterson, Fred, 1988, The Lower Jurassic Nugget Sandstone of the Uinta Mountains in northeastern Utah and its relationship to the Glen Canyon Group farther south: Geological Society of America, Abstracts with Programs, v. 20, p. A268.

Picard, M.D., 1975, Facies, petrography and petroleum potential of Nugget Sandstone (Jurassic), southwestern Wyoming and northeastern Utah, in Bolyard, D.W., ed., Deep drilling frontiers of the central Rocky Mountains: Rocky Mountain Association of Geologists Symposium, p. 109-127.

Pipiringos, G.N., 1968, Correlation and nomenclature of some Triassic and Jurassic rocks in south-central Wyoming: U.S. Geological Survey Professional Paper 594-D, 26 p.

Pipiringos, G.N., Hail, W.J., Jr., and Izett, G.A., 1969, The Chinle (Upper Triassic) and Sundance (Upper Jurassic) Formations in north-central Colorado: U.S. Geological Survey Bulletin 1274-N, p. N1-N35.

Pipiringos, G.N., and O'Sullivan, R.B., 1978, Principal unconformities in Triassic and Jurassic rocks of the Western Interior United States-A preliminary survey: U.S. Geological Survey Professional Paper 1035-A, 29 p.

Poole, F.G., and Stewart, J.H., 1964, Chinle Formation and Glen Canyon Sandstone in northeastern Utah and northwestern Colorado: U.S. Geological Survey Professional Paper 501-D, p. D30-D39.

Reading, H.G., ed., 1978, Sedimentary environments and facies: New York, Elsevier, 569 p.

Rust, B.G., 1978, Depositional model for braided alluvium, in Miall, A.D., ed., Fluvial sedimentology: Canadian Society of Petroleum Geologists Memoir 5, p. 605-625.

Schaeffer, Bobb, 1967, Late Triassic fishes from the western United States: Bulletin of the American Museum of Natural History, v. 135, p. 285-342.

Segerstrom, Kenneth, and Young, E.J., 1972, General geology of the Hahns Peak and Farwell Mountain Quadrangles, Routt County, Colorado with a discussion of Upper Triassic and pre-Morrison Jurassic rocks, by G.N. Pipiringos: U.S. Geological Survey Bulletin 1349, 63 p.

Shropshire, K.L., 1974, The Chinle and Jelm Formations (Triassic) of north-central Colorado: Boulder, University of Colorado, $\mathrm{Ph} . \mathrm{D}$. thesis, 229 p. 
Sikich, S.W., 1965, Upper Triassic stratigraphy in the eastern Uinta Mountains: The Mountain Geologist, v. 2, p. 167-172.

Stewart, J.H., Poole, F.G., and Wilson, R.F., 1972, Stratigraphy and origin of the Upper Triassic Chinle Formation and related strata in the Colorado Plateau region: U.S. Geological Survey Professional Paper 690, 336 p.

Thomas, C.R., McCann, F.T., and Raman, N.D., 1945, Mesozoic and Paleozoic stratigraphy in northwestern Colorado and northeastern Utah: U.S. Geological Survey Oil and Gas Investigations (Preliminary) Chart 16, scale 1 in. $=12$ miles.

Thomas, H.D., and Krueger, M.L., 1946, Late Paleozoic and early Mesozoic stratigraphy of !Jinta Mountains, Utah: American
Association of Petroleum Geologists Bulletin, v. 30, p. $1255-1293$.

Tweto, Ogden, Moench, R.H., and Reed, J.J. Jr., 1978, Geologic map of the Leadville $1^{\circ} \times 2^{\circ}$ Quadrangle, northeastern Colorado: U.S. Geological Survey Miscellaneous Investigations Series Map I-999, scale 1:250,000.

Van der Voo, R., Mauk, F.J., and French, R.B., 1976, PermianTriassic continental configurations and the origin of the Gulf of Mexico: Geology, v. 4, p. 177-180.

Wright, V.P., 1982, Calcrete paleosols from the lower Carboniferous Llanelly Formation, South Wales: Sedimentary Geology, v. 24, p. 671-675.

Young, Anthony, 1976, Tropical soils and soil survey: Cambridge, England, Cambridge University Press, 468 p. 




\section{SELECTED SERIES OF U.S. GEOLOGICAL SURVEY PUBLICATIONS}

\section{Periodicals}

Earthquakes \& Volcanoes (issued bimonthly).

Preliminary Determination of Epicenters (issued monthly).

\section{Technical Books and Reports}

Professional Papers are mainly comprehensive scientific reports of wide and lasting interest and importance to professional scientists and engineers. Included are reports on the results of resource studies and of topographic, hydrologic, and geologic investigations. They also include collections of related papers addressing different aspects of a single scientific topic.

Bulletins contain significant data and interpretations that are of lasting scientific interest but are generally more limited in scope or geographic coverage than Professional Papers. They include the results of resource studies and of geologic and topographic investigations; as well as collections of short papers related to a specific topic.

Water-Supply Papers are comprehensive reports that present significant interpretive results of hydrologic investigations of wide interest to professional geologists, hydrologists, and engineers. The series covers investigations in all phases of hydrology, including hydrology, availability of water, quality of water, and use of water.

Circulars present administrative information or important scientific information of wide popular interest in a format designed for distribution at no cost to the public. Information is usually of short-term interest.

Water-Resources Investigations Reports are papers of an interpretive nature made available to the public outside the formal USGS publications series. Copies are reproduced on request unlike formal USGS publications, and they are also available for public inspection at depositories indicated in USGS catalogs.

Open-File Reports include unpublished manuscript reports, maps, and other material that are made available for public consultation at depositories. They are a nonpermanent form of publication that maybe cited in other publications as sources of information.

\section{Maps}

Geologic Quadrangle Maps are multicolor geologic maps on topographic bases in $71 / 2$ - or 15-minute quadrangle formats (scales mainly $1: 24,000$ or $1: 62,500$ ) showing bedrock, surficial, or engineering geology. Maps generally include brief texts; some maps include structure and columnar sections only.

Geophysical Investigations Maps are on topographic or planimetric bases at various scales, they show results of surveys using geophysical techniques, such as gravity, magnetic, seismic, or radioactivity, which reflect subsurface structures that are of economic or geologic significance. Many maps include correlations with the geology.

Miscellaneous Investigations Series Maps are on planimetric or topographic bases of regular and irregular areas at various scales; they present a wide variety of format and subject matter. The series also includes 7 1/2-minute quadrangle photogeologic maps on planimetric bases which show geology as interpreted from aerial photographs. The series also includes maps of Mars and the Moon.
Coal Investigations Maps are geologic maps on topographic or planimetric bases at various scales showing bedrock or surficial geology, stratigraphy, and structural relations in certain coal-resource areas.

Oil and Gas Investigations Charts show stratigraphic information for certain oil and gas fields and other areas having petroleum potential.

Miscellaneous Field Studies Maps are multicolor or black-andwhite maps on topographic or planimetric bases on quadrangle or irregular areas at various scales. Pre-1971 maps show bedrock geology in relation to specific mining or mineral-deposit problems; post-1971 maps are primarily black-and-white maps on various subjects such as environmental studies or wilderness mineral investigations.

Hydrologic Investigations Atlases are multicolored or black-andwhite maps on topographic or planimetric bases presenting a wide range of geohydrologic data of both regular and irregular areas; the principal scale is $1: 24,000$, and regional studies are at 1:250,000 scale or smaller.

\section{Catalogs}

Permanent catalogs, as well as some others, giving comprehensive listings of U.S. Geological Survey publications are available under the conditions indicated below from the U.S. Geological Survey, Books and Open-File Reports Sales, Box 25425, Denver, CO 80225. (See latest Price and Availability List.)

"Publications of the Geological Survey, 1879-1961" may be purchased by mail and over the counter in paperback book form and as a set microfiche.

"Publications of the Geological Survey, 1962-1970" may be purchased by mail and over the counter in paperback book form and as a set of microfiche.

"Publications of the U.S. Geological Survey, 1971-1981" may be purchased by mail and over the counter in paperback book form (two volumes, publications listing and index) and as a set of microfiche.

Supplements for 1982, 1983, 1984, 1985, 1986, and for subsequent years since the last permanent catalog may be purchased by mail and over the counter in paperback book form.

State catalogs, "List of U.S. Geological Survey Geologic and Water-Supply Reports and Maps For (State)," may be purchased by mail and over the counter in paperback booklet form only.

"Price and Availability List of U.S. Geological Survey Publications," issued annually, is available free of charge in paperback booklet form only.

Selected copies of a monthly catalog "New Publications of the U.S. Geological Survey" is available free of charge by mail or may be obtained over the counter in paperback booklet form only. Those wishing a free subscription to the monthly catalog "New Publications of the U.S. Geological Survey" should write to the U.S. Geological Survey, $582 \mathrm{Na}$ tional Center, Reston, VA 22092.

Note.-Prices of Government publications listed in older catalogs, announcements, and publications may be incorrect. Therefore, the prices charged may differ from the prices in catalogs, announcements, and publications. 


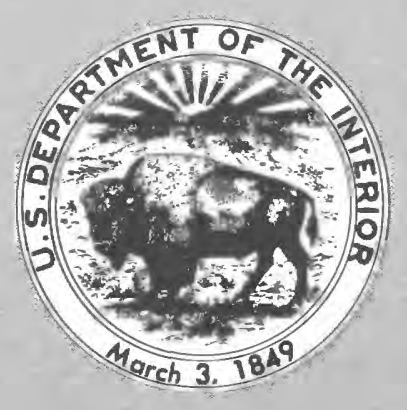

